\title{
Canids as persons: Early Neolithic dog and wolf burials, Cis-Baikal, Siberia
}

\author{
Robert J. Losey ${ }^{\mathrm{a}, \Uparrow}$, Vladimir I. Bazaliiskii ${ }^{\mathrm{b}}$, Sandra Garvie-Lok ${ }^{\mathrm{a}}$, Mietje Germonpré ${ }^{\mathrm{c}}$, \\ Jennifer A. Leonard ${ }^{\mathrm{d}}$, Andrew L. Allen ${ }^{\mathrm{e}}$, M. Anne Katzenberg ${ }^{\mathrm{f}}$, Mikhail V. Sablin ${ }^{\mathrm{g}}$ \\ ${ }^{a}$ Department of Anthropology, 13-15 Tory Building, University of Alberta, Edmonton, AB, Canada T6G 2H4 \\ ${ }^{\mathrm{b}}$ Laboratory of Archaeology and Paleoecology, Irkutsk State University, Karl Marx 1, 664003 Irkutsk, Russia \\ ${ }^{c}$ Department of Palaeontology, Royal Belgian Institute of Natural Sciences, Vautierstraat 29, 1000 Brussels, Belgium \\ ${ }^{\mathrm{d}}$ Estación Biológica de Doñana-CSIC, Avda. Américo Vespucio s/n, 41092 Seville, Spain \\ ${ }^{\text {e }}$ Department of Veterinary Pathology, Western College of Veterinary Medicine, University of Saskatchewan, 52 Campus Drive, Saskatoon, SK, Canada S7N 5B4 \\ ${ }^{\mathrm{f}}$ Department of Archaeology, University of Calgary, 2500 University Dr. N.W., Calgary, AB, Canada T2N 1N4 \\ ${ }^{\mathrm{g}}$ Zoological Institute RAS, Universitetskaya nab. 1, 199034 Saint-Petersburg, Russia
}

\author{
Keywords: \\ Canids \\ Dogs \\ Wolves \\ Dog burials \\ Siberia Hunter- \\ gatherers \\ Personhood \\ Ontologies
}

Cosmologies a b s t r a c t

\begin{abstract}
Interpretations of dog burials made by ancient foraging groups have tended to be based upon our own relationships with such animals and modern western cosmological and ontological concepts. Osteological studies of early dogs often focus only on issues of taxonomy, and as a result very little is known about these animals' life histories. Eastern Siberia has produced many Holocene dog burials, but these are typically not well described and the explanatory frameworks provided for them are very underdeveloped. Here we examine in detail two Cis-Baikal canid burials, one of a wolf and the other a dog, both in large Middle Holocene hunter-gatherer cemeteries. We link the mortuary treatment of these animals to other cultural practices, particularly the treatment of the human dead, and broader patterns in Northern human-animal relationships. This interpretive model is combined with detailed osteobiographies for the canids and contextual information for these and other dogs and wolves from Middle Holocene CisBaikal. It is argued that canids here were understood and treated in a variety of ways. We suggest that some animals with unique histories were known as distinct persons with 'souls' and because of this at death required mortuary rites similar to those of their human counterparts.
\end{abstract}

\section{Introduction}

Archaeologists often have sought to explain the meanings behind the intentional burial of dogs, a set of practices that first appears in Eurasia during the late Pleistocene. Scholars have pointed to the unique forms of social and emotional bonds people today have with dogs, and in some cases claim similar understandings were present in the far distant past. In Holocene Eurasia, relationships between humans and dogs (and more rarely wolves) have been characterized as friendship and mutual respect, burials as evidence of the animals being considered persons or companions, and canids themselves as being spiritual or metaphors for various features of society (e.g., Olsen, 1985; Nielsen and Petersen, 1993; Radovanovic, 1999; Tilley, 1996; Morey, 2006, 2010; Larsson, 1989). Aspects of these accounts probably are accurate in some ways, but the explanatory models behind them are often underdeveloped. Rarely is the specialized treatment of dogs and wolves upon death linked to other cultural practices, particularly the treatment of the human dead, and broader patterns in

\footnotetext{
$\Uparrow$ Corresponding author. Fax: +1 7804925273 .

E-mail address: robert.losey@ualberta.ca (R.J. Losey).
}

human-animal relationships. We argue here that a more convincing account of specific canid burials can be produced when detailed osteobiographies and context are combined with interpretive models that situate canid-human engagements within overarching cosmological and ontological understandings and practices.

Our particular interest is in developing a model for explaining two canid burials in the Cis-Baikal region of Siberia, including a recently recovered dog skeleton and the "wolf of Baikal" (Bazaliiskiy and Savelyev, 2003). These burials were found in two of the region's earliest and largest cemeteries, known respectively as Shamanka II and Lokomotiv-Raisovet (hereafter Shamanka and Lokomotiv). The two interments, both over 7000 years old, demonstrate that as soon as formal cemeteries developed in Cis-Baikal, some canids too began to receive mortuary treatments that closely paralleled those of humans. Other less extensively documented dog burials in this region confirm that such practices were not limited to these two cemeteries. In addition, some human graves contain canid remains modified into body ornaments or implements, and habitation sites in the region also show that wolves and dogs were at times afforded no special treatment whatsoever.

Here we employ an interpretive approach that positions human-canid relationships within a generalized model of Northern 

cosmologies and ontologies. This model posits that Northern indigenous peoples (and others) both act in and know a world that is full of persons. These persons, namely sentient, willful beings with souls, include not just humans but also implements, plants, weather phenomena, landscapes, and particularly animals. The souls of these beings cycle through the cosmos, returning to the plane of the living to inhabit a newly formed person. An essential part of this process is the proper treatment of the remains of the person, human or otherwise, following their death. Not all beings, however, are equally 'ensouled'. Some are more powerful and dangerous than others, while some are more personally known than their conspecifics. These differences in part condition how their bodies are cared for and may well account for the differential treatment given to select canids.

Knowing only that a buried skeleton is from a dog or a wolf tells us little about that animal's life and its history with humans. Various technical methods now allow us to explore in some depth the life histories of ancient individuals, whether they are human or animal. We posit that building such individual life histories should be a key element in interpreting why some canids were buried, and why others received no special treatment upon their deaths. Therefore, the second aspect of our approach involves assessment of the individual life histories and contexts of the two Cis-Baikal canids. We begin by discussing their archaeological context, and this is followed by descriptive osteology, osteometrics, and in the case of one of the canids, ancient DNA analysis. In addition, diet of both canids is examined through study of their stable carbon and nitrogen isotope ratios. We draw together these details of the canids' lives to assess and enrich our interpretive model and offer suggestions for future dog and wolf research in the region.

\section{Interpretive approach}

Numerous scholars recently have argued that indigenous peoples throughout much of the North (and elsewhere) interacted with and understood animals in ways that fundamentally differ from modern Cartesian understandings (Bird-David, 1990; Bird-David, 1999; Descola, 1992; Fausto, 2007; Gutherie, 1993; Harvey, 2006; Ingold, 1986, 1996, 1998, 2000; Pederson, 2001; Stringer, 1999; Viveiros de Castro, 1998; Willerslev, 2007). These diverse ways of engaging with and understanding the world have been grouped under the term animism. In animistic systems, humans are not the only fully sentient, emotional, and social beings. Landscapes, weather phenomena, plants, implements and particularly animals too have the potential to possess these qualities or perspectives.

In animistic systems, beings of a certain group (e.g., animals of a given species) had social lives paralleling those of humans and were known to appear to each other in human form, wielding implements, wearing clothing, and conversing in their own languages (Viveiros de Castro, 1998). Social boundaries, however, were not being-specific; humans could and did have social relations with some animals. Those social engagements often were strongest with animals that were most intimately involved with humans. These might include animals that were regularly interacted with and eaten such as 'wild' prey and domesticates, as well as those considered kin or particularly potent (Paulson, 1968, p. 452; Willerslev, 2007).

Humans and animals also engaged in complex cosmological relationships within animistic systems. Throughout much of the North, the cosmos was viewed as consisting of a series of tiers or levels, only one of which was regularly occupied by 'normal' living beings (Ingold, 1986). All persons, human and otherwise, potentially possess souls or spirits (Hulzcrantz, 1953; Ingold, 1986; Willerslev, 2007). These are in many cases finite in number-there can be only so many persons (Brightman, 1973). After death, souls move to another tier and at some later point can recycle to the tier of the living to help form a new person.

The ability of souls to recycle can be facilitated or disrupted, particularly through the treatment of the body around the time of death (Willerslev, 2007; Jordan, 2003; Paulson, 1968). Mishandling bodies, including the skeletal remains of animals that had been eaten, could anger the animal's spirit, offend its spirit master, or otherwise prevent the soul's regeneration into another being. Mishandling could involve disrespectfully addressing the animal or boasting of one's prowess in killing it, failing to make reciprocal gestures to its spirit or its master, or allowing its body to be desecrated by permitting it to be gnawed by animals such as wolves and dogs (Rasmusen, 1930, p. 108; Brightman, 1973, pp. 132 and 133; Hallowell, 1926, pp. 136, 140 and 141; Jordan 2003, p. 101; Paulson, 1968, p. 453; Ohtsuka 1994, p. 571). This was pragmatic behaviour, not merely symbolism; it helped to ensure the continued flow of animals to humans.

Paulson (1968, pp. 455-456) argued that the treatment of animal bodies after death in Northern Eurasia is closely related to concerns for bodies of the human dead. Both are persons and possess souls-proper treatment after death helps to ensure regeneration of their souls and the formation of new persons. Ceremonial sending of souls through post-mortem rites, not merely 'showing them respect', is often critical to this process. These acts of sending, which can be termed post-mortem rites, involve simple gestures that would leave little trace and elaborate processes with considerable material consequences. Relatively simple treatments might involve orienting animal heads in the appropriate direction for the post-mortem passage of their souls, while more complex procedures involve ritualized killing, consumption, and burial of the animal (e.g., Ainu bear sending ceremonies (Hallowell, 1926)).

Notably, unlike humans, many animals do not seem to have individual, unique souls but rather those that cycle back into a collective for that species (Ingold, 1986, p. 247; Jordan, 2003, p. 102; Paulson, 1968, p. 454; Vitebsky, 2006, p. 275). For example, souls of common prey animals such as wild reindeer and elk were often seen as returning to a pool for their respective species. Some animals' souls, however, retain individuality or uniqueness after death. Paulson (1968, p. 452) and Ingold (1986, p. 249) state that these typically include extremely powerful or intelligent animals such as bears, walrus, and whales, but other animals also are sometimes uniquely ensouled, including dogs (Grøn, 2005, p. 4). All such animals clearly were among those requiring the most elaborate post-mortem rites, including burial in graves like those of humans (Grøn, 2005, p. 4).

An important aspect of animistic perspectives is that any animal potentially could be a person, but people's knowledge of this in part depends on context. Animals revealed themselves as persons to humans in their engagements with them (Willerslev, 2007, pp. 116 and 117). Depending upon the nature of the interaction between humans and an animal (its duration, intensity, place), a specific animal might become known as a more distinct person than others. By default, dogs (and other domesticates) much more regularly engage with people than most other animals, but not uniformly so. It seems probable that all dogs within a forager community could be unique persons, but some more than others because of their friendliness, dependability, and unique histories with specific humans. We suspect that the combination of unique engagements with specific animals, and the variable ways in which dogs and wolves were understood more broadly, shaped their specific treatment upon death.

The Northern ethnographic record demonstrates that a singular and broad ranging characterization of dogs as companions, friends, persons, or soulless beasts is inaccurate. Willerslev (2007, p. 76) describes the general understanding of dogs among the modern 
Siberian Yukaghirs as being special, but not wholly positive. Dogs were said to be "closer to human beings than any other creature," so much that hunters sometimes referred to them as their "children." Dogs in other Siberian communities are even said to be able to act as a stand-in for someone in times of peril, offering their own life up in place of that of their human associate (Vitebsky, 2006, pp. 275-284). More rarely, some groups are said to have believed that dogs had no souls whatsoever (Spencer, 1959, pp. 465 and 456). However, even in these groups, families without children might give the name of a deceased relative to a dog, and this appears to have allowed the animal to acquire a soul. In some areas dogs were also sacrificed. This was done as an offering to spiritual beings controlling prey, as a method of swearing a blood oath, to feed the spirit of a newly built house, and even as a means of allowing their souls to accompany or to transport human souls to the afterlife (Vdovin, 1977:131, 168; Jensen, 1961; Ides and Brandt, 1967, pp. 154 and 155; Samar, 2009; Shirokogoroff, 1935, pp. 92, 200 and 210; Taksami, 1968, pp. 410 and 411). Dogs also were seen as ideal human protectors, both from animal predators and spiritual beings, and to have had the power of healing (Brewer et al., 2001; Samar, 2009; Taksami, 1968). Conversely, dogs were often considered impure and contaminating, perhaps due to their tendency to eat faeces, to carry an unpleasant odour, and be sexually promiscuous (Willerslev, 2007, p. 76; Jensen, 1961; Schwartz, 1997; Snyder and Moore, 2006; Vitebsky, 2006, pp. 88 and 89, 274-284 and 337).

Wolves have a more consistently negative standing in Siberia, where many indigenous groups herd reindeer preyed upon by these carnivores (c.f., Vitebsky, 2006). Competition with humans over reindeer, however, does not fully structure understandings of these animals even among reindeer herding groups. For example, the Yukaghir consider wolves and other predators (sable, fox, and wolverine) as potentially impure, and this possibly relates to their " uncontrolled lust to kill and their disrespectful treatment of carcasses of slain prey (Willerslev, 2007, p. 76).’' In other words, these animals behaved in ways deemed inappropriate for any person-they violated the ethic of sharing and dishonoured what they killed. In some North American cases, wolves were clearly known as soul-possessing beings of some importance while their domesticated kin-people's dogs-were said to lack souls (Spencer, 1959, pp. 268, 269 and 465).

Based on this model, we predict the following treatments of dogs and wolves to be evidenced in the archaeological record of Cis-Baikal. First, given that both dogs and wolves could be viewed from a variety of perspectives, it is predicted that these animals' remains will receive highly variable treatment upon death, from specialized care to casual abandonment. If select dogs and wolves were considered human-like persons with souls, they would have been treated in similar ways to humans upon their deaths. Only if human mortuary ritual involved burial would select dogs and wolves too be buried. Second, if wolves and other carnivores were understood as impure and contaminating, their remains likely would not be worn on the body nor included in graves with human bodies. Finally, if wolves and dogs were considered protectors or transporters of human souls, they might have been purposefully killed during mortuary rites and interred whole with certain humans. Alternatively, portions of their bodies, as substitutes for the whole and carrying the animal's effects or powers (see Conneller, 2004), might be worn by humans as items of personal adornment, even in the grave. This could involve using parts of animals that were not intentionally killed by their human companions. Such items also might have served as personal memorials for certain canids.

To utilize this model, information is needed about the variable ways in which canids were treated within a given area and time period. If cases of distinctive treatment are identified, life histories of individual animals can be built, as these, along with context, are the only ways of assessing how specific animals were interacting with humans. With our dataset, building such life histories for canids is best achieved by morphological and chemical analyses of their skeletal remains.

\section{The Baikal Middle Holocene canids}

\section{Shamanka II}

The Shamanka cemetery is located at the southwestern end of Lake Baikal (Fig. 1). This site was subject to small-scale excavations in 1999 (Turkin et al., 2005) followed by more extensive field projects from 2000 through 2008. These later investigations were led by Vladmiir I. Bazaliiskii of Irkutsk State University as part of the Baikal Archaeological Project, and have resulted in the nearly complete excavation of the site. Overall, Shamanka has produced 96 graves and at least 154 individuals from the Early Neolithic period and the mortuary tradition termed Kitoi. Multiple radiocarbon dates on human bone indicate that these graves date from $\sim 7000$ to 6100 uncalibrated years BP (Weber et al., 2006). An additional 11 graves dating to later periods and a small number of other ritual features were also identified. In 2008 and 2009, Losey (this study) analyzed the roughly 8300 modified and unmodified faunal remains from the Kitoi graves, including the canid remains described below. Shamanka human remains continue to be studied by Baikal Archaeological Project scholars.

Kitoi mortuary practices at Shamanka are quite variable, but some general patterns are evident. Most burial pits are irregular ovals capable of holding bodies in extended position, and most intact bodies uncovered were found in such position. During burial, bodies were often covered with ochre, and caches of artifacts were placed near the body, sometimes under the head. Many items of personal adornment also were found directly on human remains. Some graves included multiple simultaneous interments, while in other cases it is clear pits were sequentially utilized for burials. At least half of Shamanka Kitoi individuals (roughly 80 people) were found disarticulated, in some cases being represented by only 1-2 elements. In the majority of cases these episodes of skeletal disarticulation appear to have occurred in antiquity, apparently from instances of grave pit reuse, the reopening of graves for the handling of body parts, and nearly complete removal of some skeletons.

The array of animal remains in the graves is extensive and is only briefly reviewed here. Particularly common animal objects include a suite of implements made from deer (Cervidae) antler and bone, pendants of red deer (Cervus elaphus) and wild boar (Sus scrofa) canines, needle cases fashioned from bird wing elements, and fish hook barbs made of raptor talons. A suite of unmodified animal remains were also found including (but not limited to) musk deer (Moschus mochiferus) canines, marmot (Marmota sibirica) and hare (Lepus sp.) incisors, sable (Martes zebellina) teeth, mandibles, and crania, and more rarely mandibles from beaver (Castor fiber) and foxes (Vulpes vulpes), and os penis from brown bear (Ursus arctos). Crania and mandibles from bears were found in multiple graves, often in their upper levels. Additional bear parts were found in the sediments surrounding the graves, as were a number of artifacts and scattered human remains. These appear to have been removed from graves during grave revisiting.

Modified wolf or dog remains were found in four Kitoi graves at Shamanka. Grave 7 was an oblong pit that contained a 20-25 years old probable female at its base in extended supine position. Multiple burial accoutrements were found to the left of the body, including ten teeth from a wolf or dog. Mandibular teeth included four incisors (two left, two right), two premolars (both right), and one 


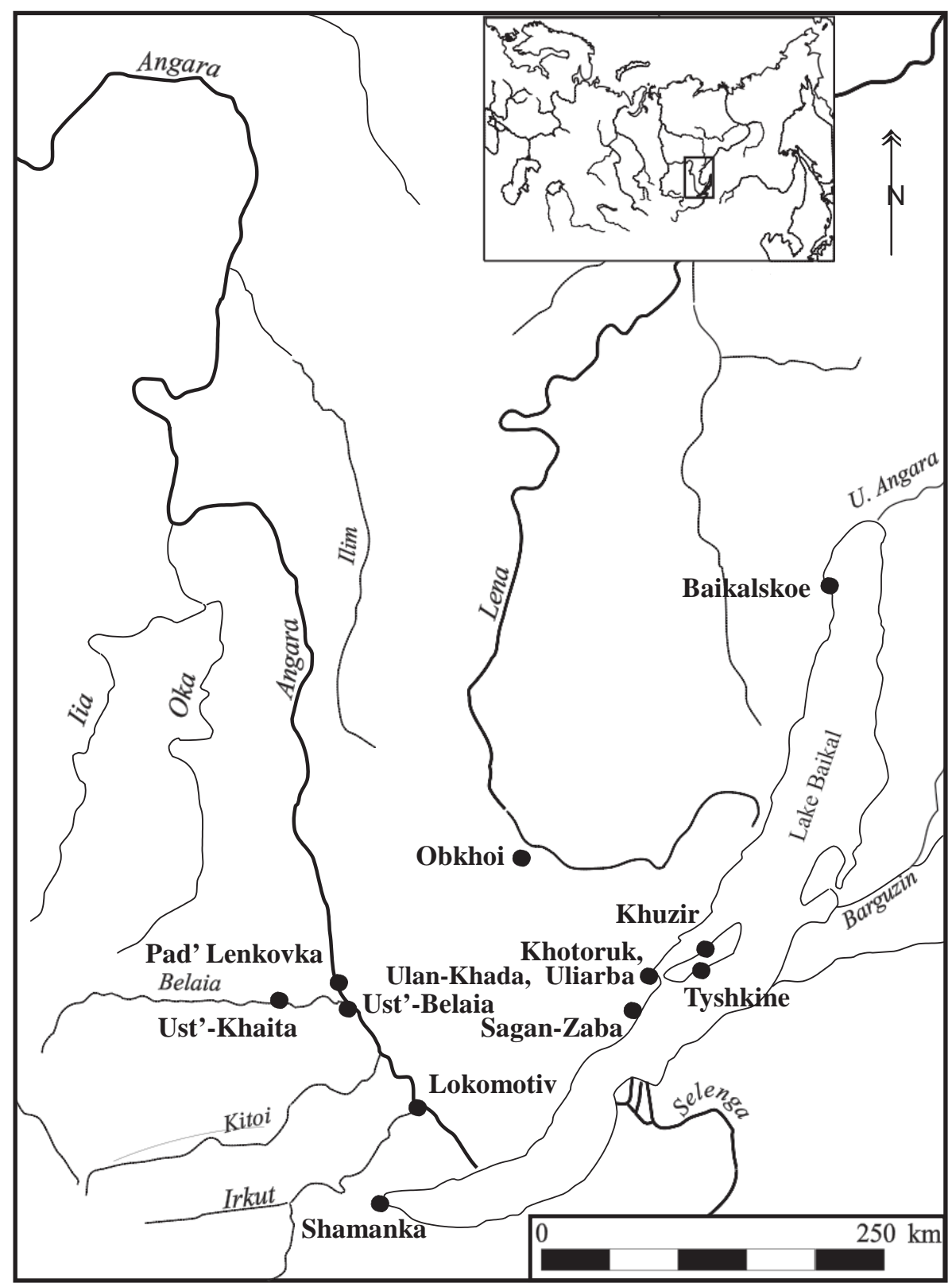

Fig. 1. Map of the study area, with locations of sites mentioned in the text indicated.

molar (right), while the upper dentition was represented by three premolars (two left, one right). All could have derived from a single individual. Two of the incisors are unmodified, while the other two were drilled through their roots, probably for the purposes of suspension. All of the post-canine teeth were heavily ground on their lingual surfaces, in one case so extensively as to fully expose the pulp cavity. Such grinding might have facilitated their attachment to a flat surface such as a container or garment. Grave 8 contained the disarticulated remains of two humans, including one 3540 year old male and 20+ year old unsexed individual. Amongst these scattered remains was a single wolf or dog right lower 4th premolar. Grave 83 also contained two highly disarticulated individuals, including a 20-24 year old male and 20-30 year old probable female. Among the nearly 200 other items found scattered in the grave were four wolf or dog incisors, all with the lateral faces of their roots ground and having biconically drilled holes at their tips (all were broken through these drilled holes). These teeth are from mandibles, and the presence of two right 2nd incisors indicates that two canids are represented.
In grave 96, a nearly complete and fully articulated skeleton of a female, aged 30-35 years, was found in extended supine position. Just over 250 artifacts were found on and around the body, including a right tibia from a canid. This specimen, found within a cluster of artifacts just to the left side of the head, had both of its epiphyses broken off. Its exterior surface appears to have been lightly ground, and the entire object was heavily stained with ochre (as were many of the other items in the grave). Similar objects, nearly always made of bird wing elements, were repeatedly found at the site (including within grave 96) and often contained within them fine sewing needles or more rarely fish hook parts.

The single canid burial at Shamanka was found within grave 26 (Fig. 2). Human remains representing a minimum of five individuals were found at various levels of the grave pit. These remains, with the exception of three sets of lower leg bones, were completely disarticulated and jumbled. These include one probable male and one probable female, both $20+$ years of age, as well as one 14-18 year old, a 7-9 year old, and a 6-8 year old, none of which could be sexed. Based on the presence of the highly disarticulated 


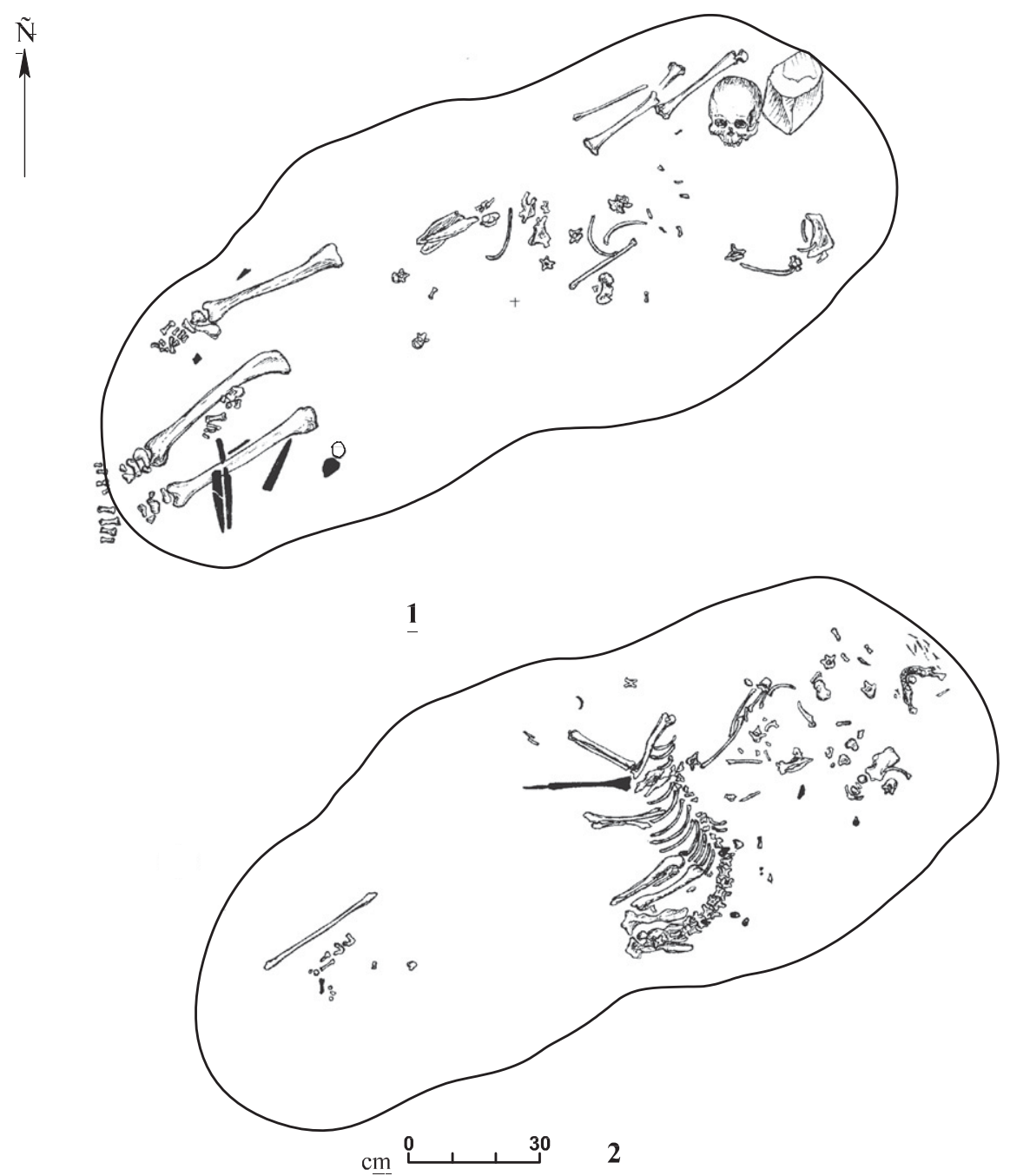

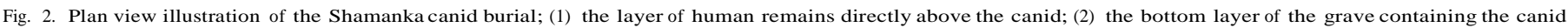
skeleton. The object shown in black immediately next to the canid is an antler spoon.

remains found scattered at all levels within the grave pit and the irregular outline of the pit itself, it appears that the grave was opened multiple times. At the base of the grave the canid was found laying on its right side with its back tightly arched and its feet curled against the body (Fig. 3). Stratigraphically, the canid appears to be the first interment in the pit. The position of the body

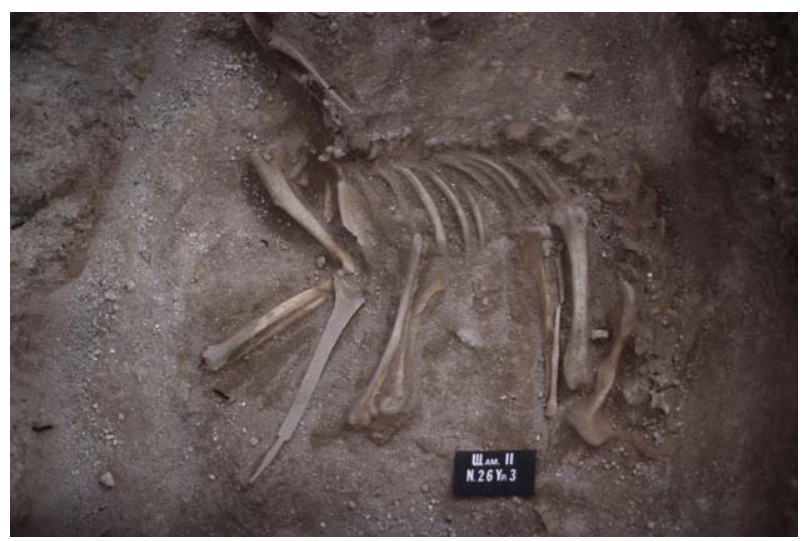

Fig. 3. The Shamanka canid in situ. Note that the cranium, one mandible, and several cervical vertebrae were found in the upper layers of the grave pit. suggests the head was originally oriented to the north-northeast. The canid's cranium, right mandible, a few foot elements, and most of its cervical vertebrae were found disarticulated in the upper portion of the grave pit at the same level as some human remains and artifacts. These elements appear to have been dislodged or removed from the rest of the skeleton in an episode of pit reuse. The left mandible was not found. The animal's os penis was uncovered in situ, indicating that it is a male. Directly associated with the post-cranial skeleton was a large antler spoon, and many scattered artifacts and human remains were also present at roughly the same grave pit level.

Four radiocarbon dates were obtained on the human remains in the grave, and one on the canid. The probable adult female produced a date of $6135 \pm 70$ (TO-11528) and the 6-8 year old a date of $6250 \pm 60$ (TO-11530). These dates both have relatively high collagen yields (1.8\% and $4.3 \%)$ and are consistent in age with that expected for the Kitoi mortuary tradition. They also are statistically the same at the $95 \%$ confidence level (test statistic $\mathrm{T}=1.55882$ ). The other two human dates were obtained on the probable adult male and the 14-18 year old individual. Both had low collagen yields $(0.7 \%$ and $0.3 \%$, respectively), and both produced dates inconsistent with the high collagen yielding samples and the Kitoi tradition in general $(4880 \pm 130$ (TO-11529) and $5270 \pm 60$ (TO11530), respectively). Elsewhere in Cis-Baikal, low collagen yielding samples have been shown to produce similarly discordant 
radiocarbon dates (Weber et al., 2005). A vertebrae from the canid produced a high collagen yield (8.3\%) date of $6430 \pm 35$ (OX20561). The sample is statistically different than the two high collagen yield dates from this grave (test statistic $\mathrm{T}=17.40489$ ). Nonetheless, the calibrated age range at two standard deviations is 72807425 BP, placing it within the Late Kitoi mortuary tradition.

Lokomotiv

The Lokomotiv cemetery is located near the confluence of the Irkut and Angara rivers within the modern city of Irkutsk, roughly $75 \mathrm{~km}$ to the north-northeast of Shamanka (Fig. 1). This massive site was excavated over multiple periods, with the first work occurring in 1927, followed by projects in the 1940s and 50s, and the 1980s and 90s (Bazaliiskiy and Savelyev, 2003, 2008). Many graves were destroyed by construction activities, and many more also likely remain unexcavated. At least 87 graves have been excavated here, but detailed information is available for only 71 , the majority of which were recovered by Bazaliiskii and Savelyev in the 1980s and 90s. Within these 71 graves were the remains of at least 124 individuals (Bazaliiskiy and Savelyev, 2003). Details on chronology, mortuary practices, human osteology, stable isotopes, and genetics already have been published in English and Russian (Link, 1999; Katzenberg and Weber, 1999; Weber et al., 2002; Bazaliiskii, 2003; Bazaliiskiy and Savelyev, 2003; Bazaliiskii and Savel'ev, 2008; Mooder et al., 2005, 2006; Weber et al., 2006; Weber et al., 2010; Lieverse et al., 2007a,b, 2009) and are very briefly reviewed here.

The 98 radiocarbon dates on human remains from the cemetery indicate that its primary period of use was roughly contemporaneous with the Early Neolithic interments at Shamanka (Weber et al., 2006). A few graves at Lokomotiv, including the single grave containing canid and human remains, date slightly earlier, with uncalibrated midpoints falling between 7000 to $8000 \mathrm{BP}$, placing them within the Late Mesolithic period (Weber et al., 2006; Bazaliiskii and Savel'ev, 2008). Based on this chronology and the structure of the artifacts and faunal remains within the graves, the vast majority of graves here were assigned to the Kitoi mortuary tradition. Specific mortuary practices are highly variable, but all involved interments in oblong and relatively deep grave pits. Both single and group burials were present, and in most cases bodies were found in extended supine position. Group burials often involved the placement of individuals in head-to-toe position. Roughly one-fourth of the individuals lack their craniums, and in many cases their removal appears to have occurred prior to burial. Burial accoutrements are similar to those seen at Shamanka.

In 2009, Losey (this study) analyzed all available faunal material from the graves, all of which derived from Bazaliiskii and Savelyev's excavations of the site in the 1980s and 90s. Preservation conditions at Lokomotiv were not as ideal as at Shamanka, but still quite good, and $\sim 2200$ faunal remains were present. As at Shamanka, these materials were dominated by implements made of deer antler, unmodified marmot incisors, pendants fashioned from the canines of red deer, wild boar, and musk deer, as well as modified and unmodified bird remains. Unmodified sable and fox teeth and mandibles were also found in several graves. The only modified large canid remains at the site consisted of a single canine found in grave 23 which had one face of its root ground to a flat surface. The object was found with a cluster of other artifacts just above the head of a human male, age 20-25 years, and lying in extended supine position.

In 1995, a complete canid burial was found in the Raisovet section of the cemetery threatened by construction activities (Bazaliiskii, 2003; Bazaliiskiy and Savelyev, 2003, 2008). This grave (\#8) was oval in outline, and at about $86 \mathrm{~cm}$ from the modern surface excavators found a fully articulated canid laying on its left side with its head oriented to the south (Figs. 4 and 5a and b). The legs of the canid were slightly flexed, and positioned between the legs and the rib cage were the articulated cranium, mandible, and 1st and 2nd vertebrae of an adult male human. The head was within its own small pit and appears to have been interred at the same time as the canid. Despite the abundant evidence for head removal,

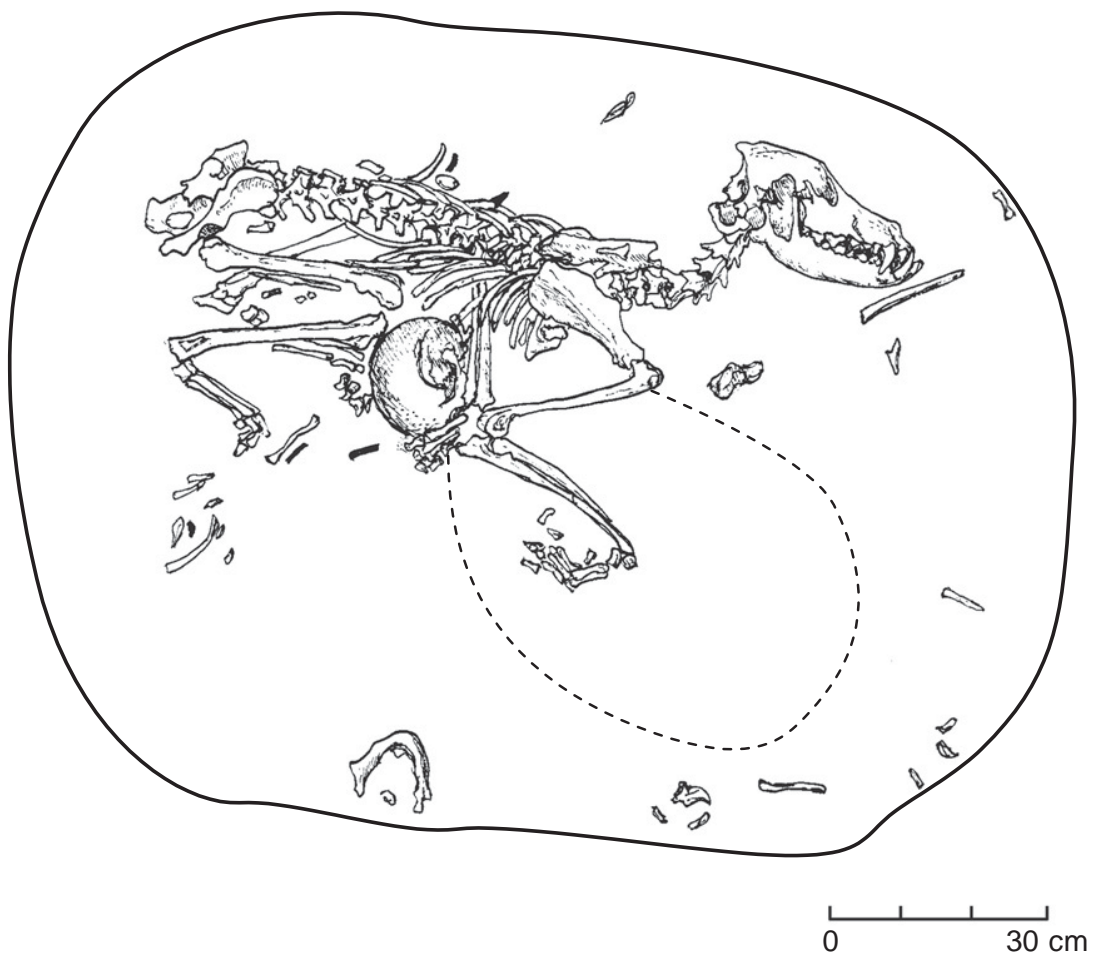

Fig. 4. Plan view illustration of the Lokomotiv canid burial. The dotted line indicates an area of ochre. 


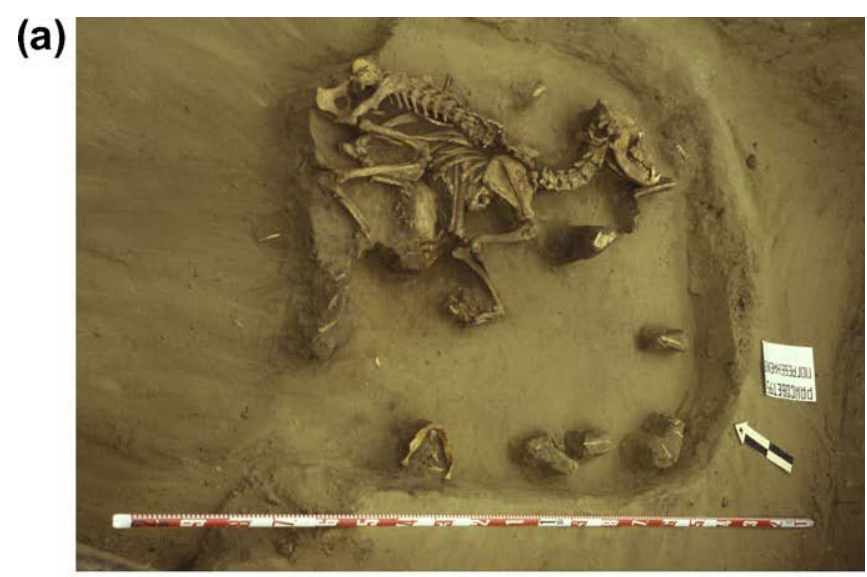

(b)

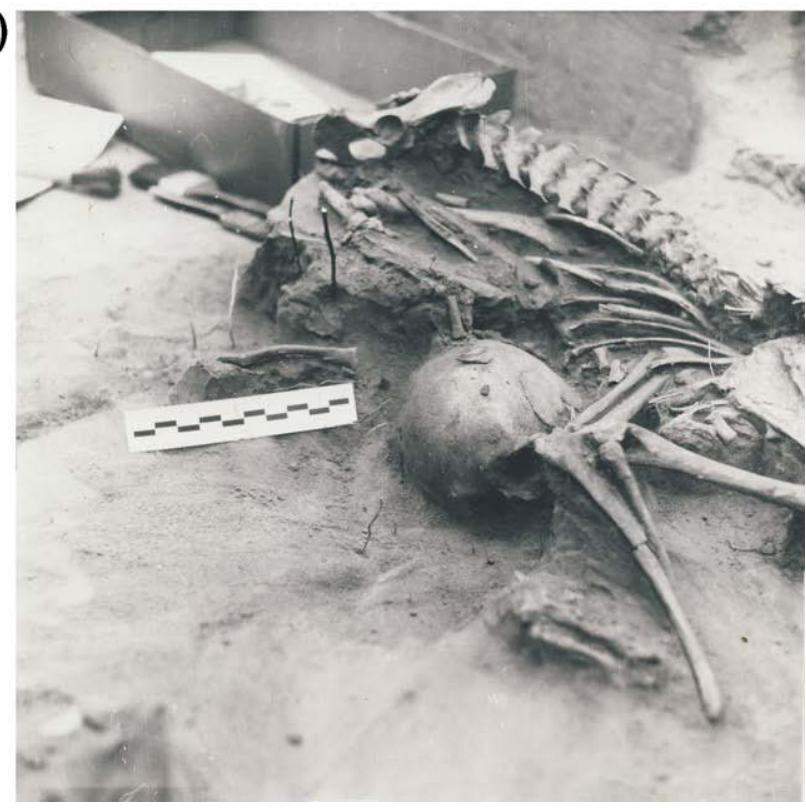

Fig. 5. (a and b) The Lokomotiv canid burial in situ (a). Photograph (b) is a close-up of the human crania positioned between the canid's legs.

this is the only isolated human head to be found at the site. A human mandible from a second individual, along with a few scattered hand bones and rib fragments, were found at the same level near the margin of the grave pit. A human fibula fragment also was found near the canid's skull. Bazaliiskii and Savelyev (2003, p. 28) suggest that these scattered human remains were from an earlier burial within the pit. A patch of ochre in the shape of an oval extended outward from the canid's front limbs. Scattered implements and ornaments in the grave included bone needles, simple lithic tools, and bone tool fragments; none were in direct association with the canid.

The canid was identified as a tundra wolf (Canis lupus albus), although no methodology for this identification is given and no measurements on the specimen's cranium or post-cranial skeleton were published (Bazaliiskii, 2003; Bazaliiskiy and Savelyev, 2003, 2008). This lack of basic analytical documentation for the canid in part stimulated the genetic and osteometric work done for this paper. Photographs of the animal in situ reveal the presence of an os penis, indicating that it is a male. Two radiocarbon dates made on groups of vertebrae and ribs from the canid were obtained: $7320 \pm 70$ (TO-11558; collagen yield 2.7\%) and $7230 \pm 40$ (GIN-8841a; no collagen yield reported) uncalibrated years BP (Bazaliiskiy and Savelyev, 2003, 2008; Weber et al., 2006). The two age assessments are statistically the same at the $95 \%$ confidence level ( $\mathrm{T}$-test value of
1.246154). At two sigma, their calibrated age ranges are between 7970 and 8320 years before present. Two dates were also obtained on the human remains in the grave. The first date, $7840 \pm 70$ uncalibrated years BP (TO-10507; collagen yield 12\%), was obtained on the atlas associated with the head buried with the canid, while the second date, $7750 \pm 70$ uncalibrated years BP (GIN-6482; no collagen yield reported), was obtained on a phalanx from the scattered human remains. The two dates are also statistically the same (T-test value of 0.8265306). Furthermore, they are the oldest of the radiocarbon dates obtained for the cemetery, with respective calibrated age ranges of $8450-8980$ and $8400-8700$ years BP. We suspect the difference between the dates on the human remains and the canid is due to an old carbon effect (perhaps a hard-water effect, see Deevey et al., 1954) in the human samples. A carbon offset for Lake Baikal has been suspected for some time (Colman et al., 1996; Prokopenko et al., 1999; Watanabe et al., 2009), and other freshwater systems are known to carry significant old carbon effects (Ascough et al., 2007; Cook et al., 2001; Fischer and Heinemeier, 2003; Geyh et al., 1998; Moreton et al., 2004). Lokomotiv itself is about $55 \mathrm{~km}$ downstream from Baikal on the Angara River, the lake's only outlet. Stable carbon and nitrogen isotope analyses of 20 human individuals from Lokomotiv indicate that the population has one of the higher $\mathrm{d}^{15} \mathrm{~N}$ averages (=14.4\%) among the region's ancient cemeteries, suggesting reliance upon freshwater fauna (Katzenberg et al., 2010). These fauna, likely a mix of local river fishes and those moving between the lake and the Angara for spawning, may also carry an old carbon effect. The Lokomotiv wolf's $d^{15} \mathrm{~N}$ values, documented as part of this study and described below, indicate that it did not rely upon the region's aquatic fauna, perhaps placing it largely outside of the chain of old carbon.

\section{Other canids}

Canid burials have been documented in other Middle Holocene sites around Lake Baikal, and we begin by reviewing those found in the region's cemeteries. In all cases described below, with the single exception of the dog from Ust'-Khaita (Klement'ev et al., 2005), methods for identifying canids are unspecified and basic osteometric data are unavailable. Even in case of the dog from Ust'-Khaita, only the crania of the specimen is described, and this was done solely for the purposes of ageing and identification.

The mortuary site known as Khuzhir or Shamanksii Mys, located on the east coast of Olkhon Island, produced 11 human graves, other pits and features, and stratified deposits containing faunal remains and artifacts (Konopatskii, 1982; Weber et al., 1998). Grave 3 (1972) contained a human burial, numerous implements and other items, and two canids. The human body was the first to be interred, and was covered or wrapped with birch poles and a sheet of sewn birch bark. Two radiocarbon dates were made on wood from the grave, which differ in their uncalibrated midpoints by just over 800 years: $5720 \pm 50$ (LE1076) and $6550 \pm 35$ (SOAN 0790) (Konopatskii, 1982:71). Just above the birch bark sheet the two canids were found, one to the left and one to the right of the human body, both on their right sides with their heads oriented to the east (as was the human burial). Both skeletons appear in Konopatskii's (1982, p. 49) illustration to have been slightly disarticulated, perhaps from the rodent burrowing mentioned in the grave description. Both were associated with implements, including chipped-stone scrapers and a knife, an antler spoon, and an additional antler implement. N.D. Ovodov, a paleontologist, identified the two canids as Siberian Huskies (Konopatskii, 1982, p. 44). Grave 4 (1973) is also reported to contain canid remains. This grave pit was large enough to accommodate the body of an adult human in extended position, but no human remains were present. Excavators found within the grave one dog mandible, a nephrite pendant and adze, and additional pendants made from animal 
teeth (Konopatskii, 1982, p. 62). No radiocarbon date is available for this feature, but the artifact styles are consistent with a Middle Holocene age.

Excavations at Khuzhir in 1973 revealed a series of stratified archaeological deposits near the graves. Slightly underneath grave 1 (1973), an oval concentration of stone slabs was found capping a pit (Konopatskii, 1982, pp. 33 and 34). At the base of the pit, a poorly preserved canid burial was found. Identified as a dog, the skeleton was articulated, on its right side, with its head oriented to the east, just as seen in grave 3 (1972). This canid too was associated with numerous artifacts, including chipped stone flakes, birch bark, a split long bone, a fragment of an antler point, and bones from the foot of an unidentified mammal. No radiocarbon dates are available for this feature, but Konopatskii (1982, p. 34) argued that it predated grave 1, which like the other burials at the site, appears to be of Middle Holocene age.

Multiple cemeteries in the Little Sea region of the Baikal west coast have produced canid remains. A few elements of a large canid were found within a human grave $(\# 4,1978)$ at the Khotoruk cemetery (Konopatskii, 1982, pp. 39-43). At the base of the grave an adult human skeleton was found. In the mid to upper portion of the grave pit, two layers of stone paving were uncovered. Near the lowermost pavement were several limb bones of mammals; at least one of these specimens was subsequently identified as belonging to a canid. At the same level within the grave were fragmented portions of a human skull and ochre. Three dates were obtained in the early 1990s on other graves at Khotoruk, and their uncalibrated midpoints range from 6550 to 7020 BP (Weber et al., 2006). Khuzhir-Nuge XIV produced an unmodified wolf canine from an unspecified location within grave 72, which contained an unsexed human adult individual (McKenzie et al., 2008). This grave was directly dated to $4410 \pm 90$ (TO-09419) uncalibrated years BP (Weber et al., 2005). Several graves at the Uliarba cemetery contained canid remains. These include a wolf mandible from grave 2, which also held one juvenile and two young adult human skeletons; three dog phalanges in grave 16, which contained one young adult individual; and an unspecified number of dog remains in graves 35 and 36, which contained one adult female each (Goriunova et al., 2004). Of these, only grave 16 was directly dated, producing an age estimate of $4290 \pm 80$ (GIN-4484) uncalibrated years BP. The canids in these latter two graves appear to be burials of whole animals that were separated from the human interments by simple stone constructions. Finally, the Kurma XI cemetery has two human graves containing dog remains, including two upper canines from grave 6 and one incisor from grave 10 (Ovodov et al., 2009). Grave 6 was directly dated to $3960 \pm 60$ (TO-10997) and grave 10 to $4050 \pm 60$ (TO-11000), both in uncalibrated years BP (Weber et al., 2006).

A spectacular, but not well dated, canid burial was found by A.P. Okladnikov at the Pad' Lenkovka cemetery located on a small tributary of the Angara a few km downstream from its confluence with the Belaia River. Grave 2 (1960) was round in outline and lined with vertically oriented stone slabs (Okladnikov, 1974, pp. 138 and 313). The interior of the construction was covered with a layer of smaller slabs. About $30 \mathrm{~cm}$ from the surface and below this stone paving, a dog or wolf skeleton was found on its right side in a tightly curled or flexed position. The sediments around the canid were charcoal-rich and contained several stone blades; a moose (Alces alces) scapula also was found near the skull. None of the archaeological materials at this site have been directly dated, and they are believed to be now lost. Okladnikov (1955, pp. 301 and 302) assigned the cemetery to the Glazkovo mortuary tradition, or Early Bronze Age period (see also Weber, 1995, p. 116).

Canid remains were also found in the Obkhoi cemetery on the Upper Lena River. Excavated in the late 1960s by A.P. Okladnikov, this cemetery contained at least 12 Glazkovo graves (Weber, 1995, p. 121). Unfortunately, no report on these excavations has been published. Mamonova and Sulerzhitskii (1989) report a radiocarbon date for grave 4 of $3760 \pm 40$ (GIN4106) uncalibrated years BP.

Habitation sites (those used primarily for residential purposes as opposed to human mortuary rites) in the Baikal region also contain wolf and dog remains. Ust'-Belaia, a large Early and Middle Holocene habitation site at the mouth of the Belaia River, produced four canid burials. In a layer originally assigned to the Mesolithic, a pit was found with an articulated canid skeleton at its base (Medvedev, 1971, pp. 63 and 64; Berdnikova, 2001, p. 119). The skeleton, identified as a dog, had its head oriented to the northeast and was laying on its left side. Four red deer canine pendants were found on its neck, two on each side, almost certainly from a necklace worn by the canid. At the same level just north of the dog's head were found large Bovidae elements, including a scapula and horn core, and at least two whole roe deer antlers-all rare grave inclusions for the region. Berdnikova (2001, p. 130) reports a radiocarbon date of $5770 \pm 35$ (SOAN-2715) on one of these associated bones. One other pit from this same area also contained an articulated canid pup skeleton (Medvedev, 1971, p. 60; Berdnikova, 2001, p. 118), along with several tools.

Two other dog pit burials were found at Ust'-Belaia in association with deposits identified as Neolithic in age (Krizhevskaia, 1978, p. 77; Berdnikova, 2001, pp. 123-125). One was found at the base of a pit laying on its back with its head oriented to the south-southwest. The canid was identified as Husky-like in form and is reported as being six years of age. Krizhevskaia's (1978, p.

77) description and illustration indicates that the canid's skeleton was at least partially in anatomical order. No associated artifacts were noted, but a hearth was built directly above it within the pit. The final canid was found disarticulated and possibly intentionally dismembered-it was found in two sections, with its front and back halves being separated and out of position. Its upper section was on its back (the ventral face of the cranium and mandible were pointed upward) and the head was oriented to the west. The right mandible from a second canid was found directly underneath its skull. No other items accompanied this burial. Ermolova (1978, pp. 42-44) very briefly describes similar dog burials at two other Neolithic habitation sites (Semenoka and Riutino) on tributaries of the Angara.

Upstream on the Belaia River, excavations at the Ust'-Khaita habitation site have revealed numerous canid remains (Klement'ev et al., 2005). Here, however, none appear to have come from intentionally buried animals. Paleontologist A. Klement'ev identified 39 wolf specimens representing a minimum of five individuals, all from layers dating to the Early and Middle Holocene. A further 129 specimens representing a minimum of five individuals were identified as dog from these same layers. Many of these were randomly scattered across the site. Some were found in a single loose concentration in layer 9 and appear to be from a single dog. Other faunal remains from this layer yielded radiocarbon dates of $8275 \pm 100$ (SOAN-4650) and $8350 \pm 175$ (SOAN-4651), making this potentially the earliest dog from the region. The animal was estimated to have been 9-11 months old based on the degree of cranial suture fusion, and its skeleton showed no pathologies.

Near the northern end of Lake Baikal, the Baikalskoe III habitation site yielded nine fragmented canid specimens representing a minimum of two individuals. These remains were recovered from layers dating to the mid- to late-Holocene (Emel'ianova et al., 2009). Excavations at Ulan-Khada, located in the southern Little Sea area, produced burnt canid cranial and mandible fragments from one of its Neolithic layers, and 19 canid remains (17 of which are likely from a single dog) from a Late Bronze Age layer (Nomokonova et al., in press). Berloga, also located on the Little 
Sea, produced a single large canid metatarsal in a layer dating to roughly 6500 uncalibrated years BP (Nomokonova et al., 2009). Tyshkine III, on the east coast of Olkhon Island, yielded a single canid bone, identified as a dog, from a Bronze Age layer (Goriunova et al., 2007). Further south along the east coast of the lake at Sagan-Zaba II, undifferentiated large canid remains were found in two Neolithic layers in association with other fragmented faunal remains (Nomokonova personal communication, 2010).

\section{Technical analyses}

\section{Osteology}

To better understand the nature of the interaction between humans and the canids buried at Shamanka and Lokomotiv, a series of technical studies were conducted, beginning with basic descriptive osteology. Initially, the two canids' crania and mandibles were measured with a digital caliper (following Von den Driesch (1976) and Morey (1992)), and the long bones with an osteometric board

Table 1

Measurements, in $\mathrm{mm}$, of the Shamanka and Lokomotiv canids. VDD is Von den Driesch (1976), MY is Morey (1992), GL is greatest length.

\begin{tabular}{|c|c|c|}
\hline Measurement & Shamanka & Lokomotiv \\
\hline \multicolumn{3}{|l|}{ - Cranial } \\
\hline VDD 1 & 215.92 & 266.03 \\
\hline VDD 2 & 199.47 & 251.06 \\
\hline VDD 3 & 189.22 & 235.02 \\
\hline VDD 4 & 59.44 & 57.20 \\
\hline VDD 5 & 130.52 & 176.68 \\
\hline VDD 7 & 104.13 & 123.88 \\
\hline VDD 8 & 109.74 & 139.26 \\
\hline VDD 9 & 123.68 & 159.42 \\
\hline VDD 10 & 82.28 & 100.96 \\
\hline VDD 12 & 94.03 & 123.74 \\
\hline VDD 13A & 104.99 & 133.55 \\
\hline VDD 14 & & 46.28 \\
\hline VDD 14A & 33.50 & 42.34 \\
\hline VDD 15 & 71.62 & 91.97 \\
\hline VDD 16 & 19.93 & 24.82 \\
\hline VDD 17 & 55.88 & 74.27 \\
\hline VDD 18 & 31.39 & 26.85 \\
\hline VDD 19 & 20.65 & 27.04 \\
\hline VDD $20 \mathrm{~L}$ & 14.98 & 16.65 \\
\hline VDD 21L & 10.16 & 9.77 \\
\hline VDD 22 & 24.98 & 30.54 \\
\hline VDD 23 & 74.50 & 85.41 \\
\hline VDD 24 & 74.11 & 82.73 \\
\hline VDD 25 & 44.03 & 51.76 \\
\hline VDD 26 & 57.48 & \\
\hline VDD 27 & 22.23 & 26.34 \\
\hline VDD 28 & 12.30 & 18.43 \\
\hline VDD 29 & 60.03 & 65.76 \\
\hline VDD 30 & 120.41 & \\
\hline VDD 31 & 41.03 & 44.06 \\
\hline VDD 32 & & 59.07 \\
\hline VDD 33 & 42.49 & 47.96 \\
\hline VDD 34 & 70.74 & 91.29 \\
\hline VDD 35 & 38.08 & 49.63 \\
\hline VDD 36 & 42.39 & \\
\hline VDD 37 & 30.23 & 38.33 \\
\hline VDD 38 & 67.21 & 79.77 \\
\hline VDD 39 & 59.98 & 74.28 \\
\hline VDD 40 & 49.16 & 70.04 \\
\hline MY IM2 & 103.21 & 141.21 \\
\hline MY OI & 94.73 & 122.86 \\
\hline MY P3 & 12.44 & 17.61 \\
\hline \multicolumn{3}{|l|}{ Long bones } \\
\hline Humerus GL & 181 & 237 \\
\hline Ulna GL & 218 & 261 \\
\hline Radius GL & 181 & 233 \\
\hline Femur GL & 203 & 256 \\
\hline Tibia GL & 199 & 258 \\
\hline
\end{tabular}

(Table 1). Second, both were macroscopically examined for evidence of trauma and pathologies, and elements were digitally photographed.

The Shamanka canid had a fully fused post-cranial skeleton and adult dentition. The maxillary left incisor 1 and right incisors 1 and 2 were lost prior to death and their alveoli filled with bone. Both maxillary canines were extensively worn, with very little of the crowns remaining, and the post-canines also showed wear. The right mandible had well worn teeth and appears to have lost premolar 1 prior to death, as no alveolus for this tooth was evident. Cranial sutures, particularly those in the facial area, were not fully fused as would occur in a senescent dog or wolf (Fig. 6). Nonetheless, the tooth loss and wear, and the fully fused post-cranium skeleton, suggest to us that the animal was a fully mature adult.

The limbs and pelvis of the canid appeared normal, showing no evidence of trauma or pathological lesions. Greatest length measurements of the long bones were used with Harcourt's (1974) formulas to estimate shoulder height. The estimates for the canid ranged from 59.1 to $62.4 \mathrm{~cm}$. Unlike the limbs, the spine and ribs showed some irregularities and evidence of trauma. Right ribs 10 and 11 showed evidence of recently healed fractures just below their necks. Thoracic vertebra 8 or 9 was found in two parts with the body and arch forming one part, and the dorsal spinous process forming the other. The part composed of the body and arch contained the cranial articular surfaces while the part composed of the spinous process contained the caudal articular surfaces. Roughening and bone proliferation was present at the fractured dorsal aspect of the arch and at the fractured ventral aspect of the spinous process. These changes are interpreted to represent an ante-mortem fracture and callus formation associated with fracture healing. The etiology of this facture and those of the nearby ribs are unknown, but fractures in these same areas are common in other studies (Warren, 2000; Teegan, 2002). Previous studies of similar fractures suggest they could be symptomatic of blows from humans, conflict with prey or other dogs, or the use of canids as burden animals (see Morey (2010, pp. 93-97) and references therein). The Shamanka specimen's lumbar vertebrae all have mild to moderate asymmetry of the vertebral arch, including the articular surfaces, and mild to moderate curvature of the spinous processes (Fig. 7). It is possible that such deformations were produced by recurrent use of the dog as a burden animal. Warren (2000) noted very similar deformed vertebrae in dogs from the southeastern United States, where the use of dogs as burden animals was also suspected. Finally, two of the lumbar vertebrae also show relatively small amounts of periarticular (intervertebral) bone formation (spondylosis) at both the cranial and caudal aspect of the

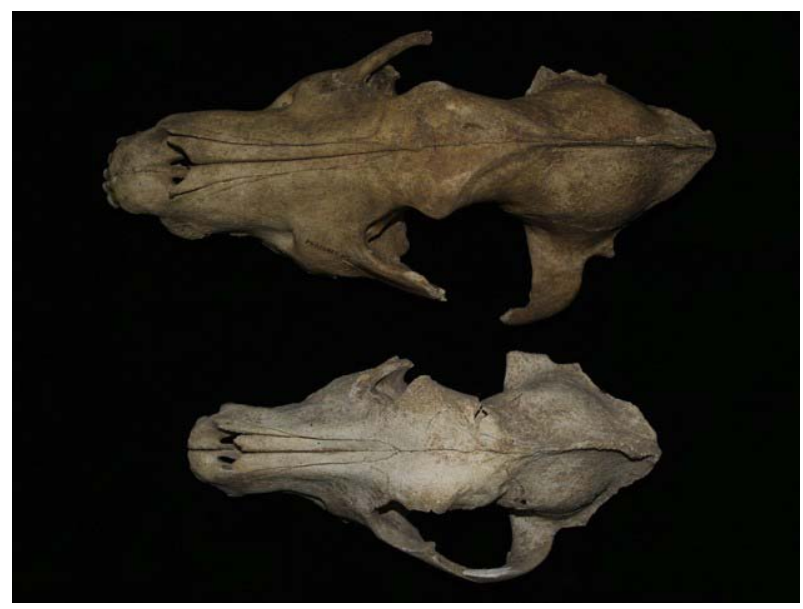

Fig. 6. Crania from the Lokomotiv (upper specimen) and Shamanka (lower specimen) canids. 
body (Fig. 7). Spondylosis is most commonly seen in dogs of advanced age (Morgan, 1967), and again has been linked in several studies to the use of dogs as burden animals (Morey, 2010, pp. 93-97).

The Lokomotiv specimen (Fig. 6) had a fully fused post-cranial skeleton and an adult dentition. In the early 1990s, G.A. Klevezal thin-sectioned one of the teeth to observe incremental cementum bands for the purposes of ageing and determining season of death. In a letter to Bazaliiskii, she stated that the specimen was $9 \pm 1$ years old and died between June and August. Our inspection of the animal's dentition also suggests an advanced age. All teeth are heavily worn, with all of the upper incisors being worn to the point of exposing the pulp cavities. The upper left canine was lost ante-mortem and its alveolus is filled with bone. This area is also associated with swelling, roughening, and porosity of the external (periosteal) surface. Most of the crown and the caudal root of the upper premolar 2 were lost ante-mortem. The left premolar 4 appears to have fractured, possibly ante-mortem, with loss of the caudal aspect of the tooth. The lingual alveolus is partially filled with bone, and a large abscess formed in the area of the labial root. All mandibular teeth are also extensively worn. In the left mandible, premolar 2 was lost ante-mortem, with the alveolus slightly remodeled. The crown of adjacent premolar 3 was fractured away ante-mortem and the break surface is slightly worn. In the right mandible, molar 2 was lost ante-mortem and the alveolus partially filled with spongy bone.

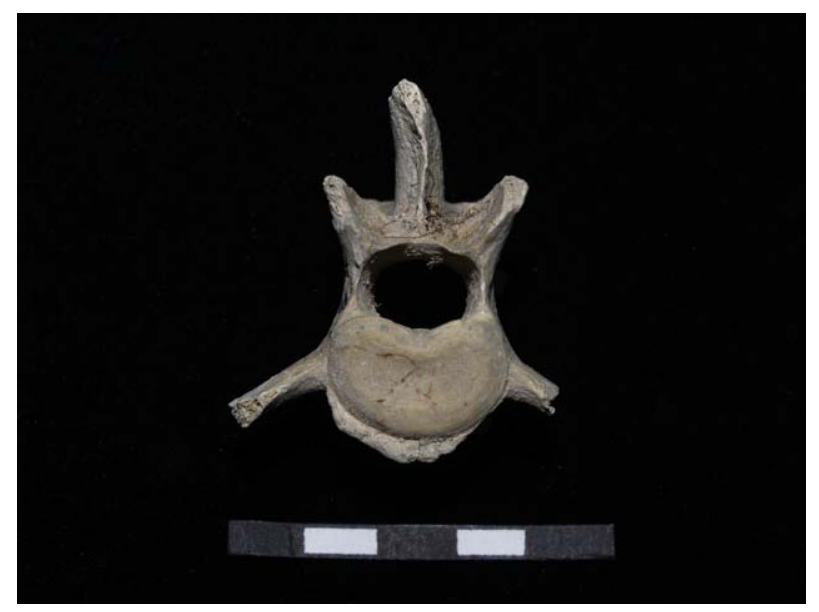

Fig. 7. Lumbar vertebra from the Shamanka canid. Note the deformed spinus process and the spondylosis present along the ventral cranial aspect of the body.

Table 2

Primers used to amplify mitochondrial DNA.

\begin{tabular}{lll} 
Primer & Sequence & References \\
\hline uCB51 & $5^{0}$-CCAACATCCGTAAATCCCACCC & Barnett et al. (2005) \\
cCB52 & $5^{0}$-CCGTAGTTAACGTCTCGGC & Leonard et al. (2000) \\
cCB53 & $5^{0}$-CCTATTCCTAGCCATACACTACA & Leonard et al. (2000) \\
uCB54 & $5^{0}$-CCATGAGGCCAAATATCCTT & \\
cCB55 & $5^{0}$-ATCTGCCTATTCATGCACGTA & Leonard et al. (2000) \\
cCB56 & $5^{0}$-GAAGCCYCCTCAGATTCAYTC & Leonard et al. (2000) \\
ThrL & $5^{0}$-CAATTCCCCGGTCTTGTAAACC & Vilà et al. (1999) \\
dog1R & $5^{0}$-GGTGATTCAATATATGAATGTAG & \\
dog2F & $5^{0}$-CTTAAACTATTCCCTGACGC & \\
dog2R & $5^{0}$-CATGCTTATATGCATGGGGC & Muñoz-Fuentes et al. (2010) \\
dog3F & $5^{0}$-CCTATGTACGTCGTGCATTAATG & \\
dog3R & $5^{0}$-CCTTATTGGACTAGGTGAT & Leonard et al. (2002) \\
ddI7 & $5^{0}$-TATTATATCCTTACATAGGAC & \\
dog4R & $5^{0}$-AGAAGAGGGACATTAC & Muñoz-Fuentes et al. (2010) \\
dog5F & $5^{0}$-CGAGAAACCATCAACCCTTGC & Leonard et al. (2002) \\
DLHc & $5^{0}$-CCtgaggtaagaaccagatg &
\end{tabular}

The limbs and pelvis of the canid appeared normal, showing no evidence for trauma or pathologies. Very minor osteoarthritis was observed in elements of the feet. Unfortunately, all but two of the vertebrae and a few fragments of the ribs were unavailable for study, the remainder being destroyed during radiocarbon dating. These showed no signs of trauma or disease, and close inspection of ribs and vertebrae in photos taken during excavation revealed no obvious abnormalities. Long bone measurements (Table 2) entered into Harcourt's (1974) formulas produced shoulder height estimates of $73.2-79.1 \mathrm{~cm}$.

\section{Osteometric identification}

The Shamanka and Lokomotiv skulls were compared to seven reference groups: the Wild Wolf, Palaeolithic Dog, Prehistoric Dog, Recent Archaic Dog, Recent Other Dog with wolf-like snout, Recent Other Dog with short tooth row, and the Recent Other Dog with slender snout group. Details on the reference groups can be found in Germonpré et al. (2009). The Pleistocene wolves recognised in Germonpré et al. (2009) were included in the Wild Wolf group. Furthermore, in this study, 54 recent wolf skulls, nearly all from northern Alberta, Canada, were adjoined to the Wild Wolf group. The Recent Archaic Dog group was enlarged with three specimens: two Husky-type skulls and one Samoyed skull.

Because multivariate statistical procedures do not allow missing values, a selection of measurements was made to include a maximum number of fossil skulls that are often incomplete. Following variables from Von Den Driesch (1976) were retained: total skull length (TL, 1), viscerocranium length (VL, 8), alveolar length P1-M2 (ALP1-M2, 15), carnassial crown length (P4CL, 18), greatest braincase width (GWbrc, 29), greatest palatal width (GWpal, 34), and minimal palatal width (MWpal, 35).

Univariate and multivariate statistical analyses were undertaken using JMP (version 5.1.2) and significance was set at $<0.05$. A linear discriminant function analyses (DFA) was generated between the specimens from the different groups. It is applied to the seven log-transformed size-adjusted variables used in Germonpré et al. (2009). The Shamanka and Lokomotiv skulls are added as ungrouped specimens in order to assign them to one of the reference groups.

The attribution of the two skulls to one of the seven classified groups was determined by the size-adjusted DFA. Wilks' lambda is very low implying high case predictability $(\mathrm{k}=0.055$, $\mathrm{P}<0.0001)$. The first two functions account together for $90.1 \%$ of the variation among the groups. The DFA allowed clear separation of the canid groups: $88 \%$ of the cases are correctly classified. In total, 20 skulls are misclassified. Between $70.6 \%$ and $100 \%$ of the skulls from the different reference groups are correctly classified. The reference group with the largest percentage (29.4\%) of misclassified specimens is the Recent Other Dog with wolf-like snout group. The Epigravettian Eliseevichi skull 447 is assigned to the group of the Recent Archaic Dogs, bringing the frequency of misclassified Palaeolithic Dogs to $20 \%$. In the Wild Wolf group, one skull was misclassified as Recent Other Dog with slender snout (1\%) and ten as Recent Other Dog with wolf-like snout group (9.6\%). Two skulls of the Recent Archaic Dogs are misclassified to the Palaeolithic dogs (9.5\%). In the Recent Other Dog with short tooth-row group, one skull was assigned to the Recent Other Dog with wolf-like snout group (9.1\%).

Fig. 8 presents the results of the assignment of the unknown specimens. The Lokomotiv skull is situated very near the centroid of the Wild Wolf group, confirming the identification of the Lokomotiv skull as a wolf (Bazaliiskiy and Savelyev, 2003). It is attributed to the Wild Wolf group with a posterior probability of 0.90 . The Shamanka skull falls just outside the range of the Recent Archaic dogs that consist of breeds such as Siberian Husky, Chow 


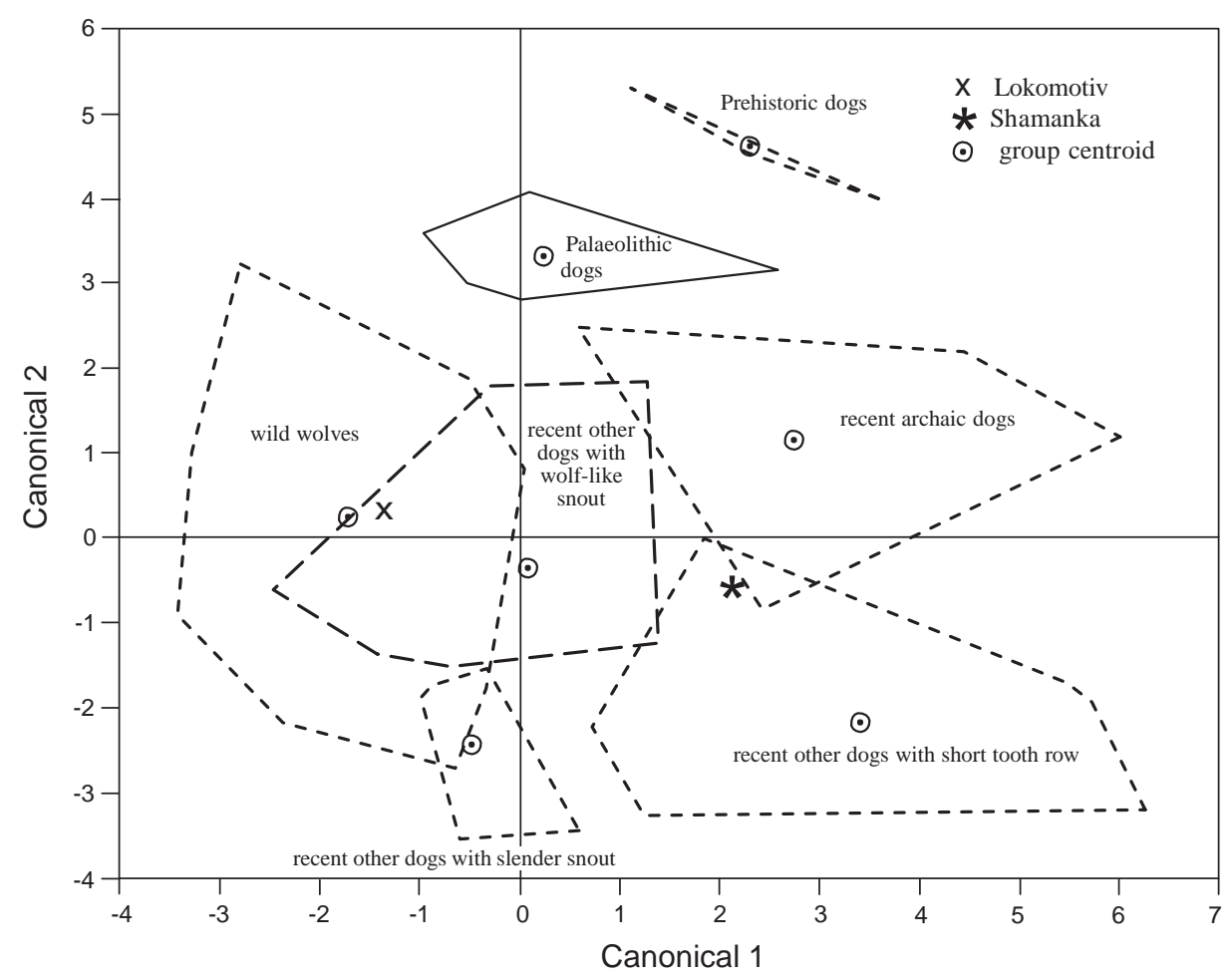

Fig. 8. Discriminant function analysis showing the first two discriminant functions performed on all groups using all indices (log10-transformed).

Chow and Samoyed, and is assigned to this group with a posterior probability of 0.64 .

\section{DNA analyses}

Given that wolf burials are quite unusual (but seen elsewhere, see Fladerer et al., 2009; Salcher-Jedrasiak and Umgeher-Mayer, 2010), we sought to further verify its identification through ancient DNA analyses. Bone preparation, DNA isolation and polymerase chain reaction (PCR) set-up were all performed in a dedicated, spatially isolated ancient DNA laboratory using all standard ancient DNA precautions. Negative controls were included with each extraction and PCR.

Two separate fragments of a vertebra were crushed and approximately $0.1 \mathrm{~g}$ of each was decalcified overnight in $5 \mathrm{~mL}$ of $0.5 \mathrm{M}$ EDTA $(\mathrm{pH}$ 8). The decalcified bone was then digested in $6 \mathrm{ml}$ of $0.01 \mathrm{M}$ Tris, $0.01 \mathrm{M} \mathrm{NaCl}, 1 \% \mathrm{SDS}$, DTT and proteinase $\mathrm{K}$ rotating overnight at $37^{\circ} \mathrm{C}$. DNA was then extracted from the digestion mix twice with $6 \mathrm{ml}$ of phenol and once with $6 \mathrm{ml}$ chloroform. The extract was further purified and concentrated with YM-30 Centricon (Millipore) filters to a final volume of about $100 \mathbf{1 L}$.

Fragments of the mitochondrial DNA were amplified in $25 \mathbf{1 l}$ reactions including $3 \mathbf{~} \mathbf{l}$ of extract. Reactions contained $1 \times$ buffer, $2.5 \mathrm{mM} \mathrm{MgCl}_{2}, 0.2 \mathrm{mM}$ dNTPs, $1 \mathrm{IM}$ of each primer and $2.5 \mathrm{U}$ AmpliTaq Gold (Applied Biosystems). Primer sets attempted include the cytochrome b primers uCB51 and cCB52 (223 bp), cCB53 and uCB54 (276 bp), and cCB55 and cCB56 (231 bp) and the control region primers ThrL and $\operatorname{dog} 1 \mathrm{R}$ (148-149 bp), dog2F and $\operatorname{dog} 2 \mathrm{R}$ (139-141 bp), dog3F and $\operatorname{dog} 3 \mathrm{R}$ (149 bp), ddl7 and $\operatorname{dog} 4 \mathrm{R}$ (148-149 bp) and dog5F and DLHc (108 bp) (see Table 2). The PCR conditions were an initial 5 min denaturation step at $95{ }^{\circ} \mathrm{C}$ followed by 20 cycles of $95{ }^{\circ} \mathrm{C}$ for $30 \mathrm{~s}$, touchdown $0.5{ }^{\circ} \mathrm{C} / \mathrm{step}$ from 60 to 50 for $1 \mathrm{~min}$, and extension at $72{ }^{\circ} \mathrm{C}$ for $1 \mathrm{~min}$ followed by 40 cycles of $95{ }^{\circ} \mathrm{C}$ for $30 \mathrm{~s}, 48{ }^{\circ} \mathrm{C}$ for $1 \mathrm{~min}$ and $72{ }^{\circ} \mathrm{C}$ for $1 \mathrm{~min}$ with a final elongation step of $7 \mathrm{~min}$ at $72{ }^{\circ} \mathrm{C}$. The ramp time between denaturation and annealing and between annealing and extension was slowed from $3{ }^{\circ} \mathrm{C} / \mathrm{s}$ to $1{ }^{\circ} \mathrm{C} / \mathrm{s}$. All PCRs included negative PCR controls and the extraction negative controls. All reactions were checked on agarose gels stained with ethidium bromide, and all bands were directly sequenced in both directions with the same primers as were used in the PCR.

A BLAST search (http://www.ncbi.nlm.nih.gov/genbank) was made with each clean sequence to determine taxa of origin, to make ensure it was canid and not a common reagent contaminant such as human or cow (Leonard et al., 2007). Sequences of canid origin were checked against replicates of the same fragment, and overlapping fragments. A phylogenetic analysis of the concatenated sequence and previously published dog and wolf sequences (Vilà et al., 1997, 1999) was performed using the neighbour-joining algorithm and an HKY85 distance using a gamma distribution with parameter a $=0.5$ in the programme PAUP $^{+}$(Swofford, 2002) (Fig. 9). Coyote (Canis latrans) and Indian wolf haplotypes (Sharma et al., 2003) were used to root the phylogeny.

None of the slightly longer (223-276 bp) cytochrome b primer sets yielded any products. Four of the five control region primer sets, all of which target products less than 150 bp including primers, did yield results. No canid DNA was identified in any negative control, but human DNA was identified in one reaction (with primer set $\operatorname{dog} 5 \mathrm{~F} / \mathrm{DLHc}$ ) that most likely originated from the reagents (Leonard et al., 2007). No mismatches were identified in any of the replicate sequences of the same fragment or between overlapping regions of adjacent fragments. A total of 333 bp (excluding primers) of sequence were determined.

The sequence of the Lokomotiv sample was not identical to any previously published sequence available in GenBank. Further, it was not in any of the four main dog clades. It was, however, very closely related to Asian and Eurasian wolf haplotypes (Fig. 9). This implies that these bones came from a wolf and not a dog. The wolves of Asia have been very much less well sampled than wolves from Europe and North America, so it is possible that this haplotype is extant in the region, but has just not been sampled. 


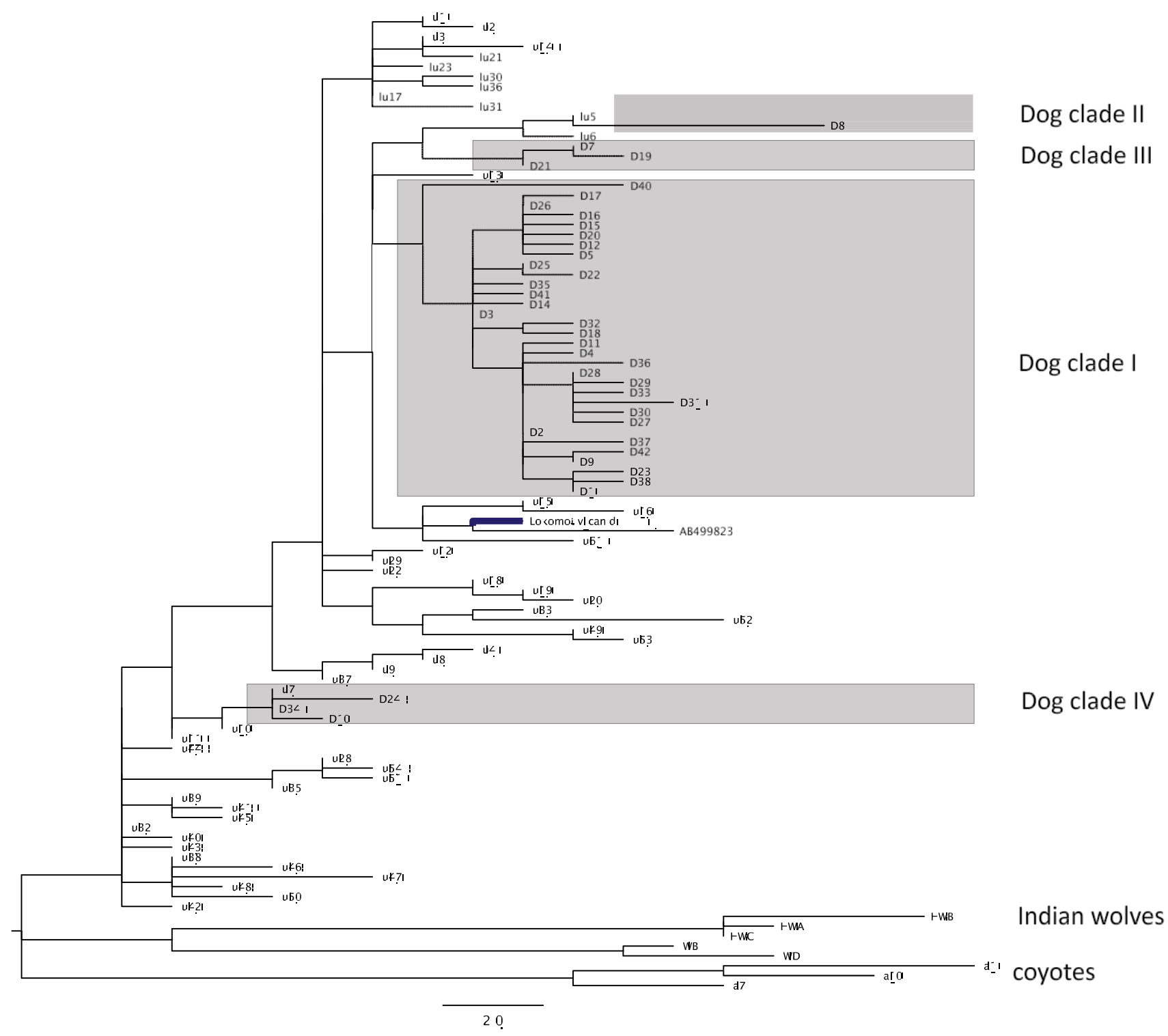

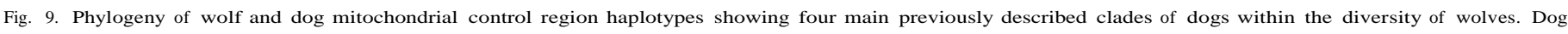

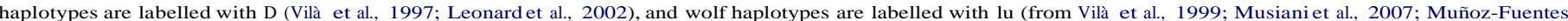

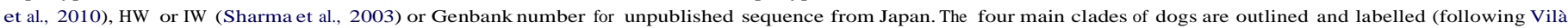

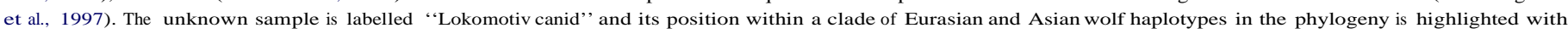
bold branch. The phylogeny is rooted with Indian wolves (HW and IW) and coyotes (la).

Stable isotope analysis

Stable isotope analyses of dog remains often indicate diets similar to those of the humans the animals lived with (e.g. Katzenberg, 1989; Cannon et al., 1999; White et al., 2001; Boric et al., 2004; Fischer et al., 2007; Allitt et al., 2008; Eriksson et al., 2008; Fornander et al., 2008; Le Bras-Goude and Claustre, 2009). To see if this was true for the Shamanka dog, and to investigate the possibility that the Lokomotiv wolf lived with humans for some time prior to its death and shared their food, we performed $d^{13} \mathrm{C}$ and $\mathrm{d}^{15} \mathrm{~N}$ analysis on bone samples from the remains (see Table 3). Dentine collagen was also analyzed in order to compare the diets consumed in the animals' youth to those consumed in the years prior to death; the results of that work will be reported in an upcoming paper treating dental development and dentine collagen analysis in canids.

To prepare the bones for analysis, a small sample weighing $\sim 0.5 \mathrm{~g}$ was cut from the bone. The exterior surfaces of the sample were removed using a motor tool with a grinding bit and the samples were cleaned ultrasonically in purified water. Samples were demineralized by soaking in repeated changes of $1 \% \mathrm{HCl}$ solution (Sealy, 1986), then treated with $0.125 \mathrm{M} \mathrm{NaOH}$ for $20 \mathrm{~h}$ to remove humic and fulvic acid contaminants (Katzenberg and Weber, 1999). Prepared collagen samples were analyzed in the Biogeochemical Analytical Laboratory of the Department of Biology, University of Alberta using a EuroVector elemental analyzer (Model: EuroEA3028-HT) interfaced to a GV Instruments (Isoprime) isotope ratio mass spectrometer. Instrument precision was $\pm 0.1 \%$ for $\mathrm{d}^{13} \mathrm{C}$ and $\pm 0.2 \%$ for $\mathrm{d}^{15} \mathrm{~N}$. Sample preservation was assessed from atomic $\mathrm{C} / \mathrm{N}$ ratio, \%C, \%N and collagen yield, using generally accepted threshold values (Ambrose, 1990; van Klinken, 1999).

The results of the analysis indicate that both samples are adequately preserved (see Table 3 ). The $\mathrm{d}^{13} \mathrm{C}$ and $\mathrm{d}^{15} \mathrm{~N}$ values of the two canids differ markedly. The Shamanka dog values $\left(\mathrm{d}^{13} \mathrm{C}=-16.1 \%\right.$, $\mathrm{d}^{15} \mathrm{~N}=13.0 \%$ ) fall close to human $\mathrm{d}^{13} \mathrm{C}$ and $\mathrm{d}^{15} \mathrm{~N}$ values from both Shamanka and Lokomotiv, showing similar $\mathrm{d}^{13} \mathrm{C}$ 
Table 3

Stable isotope values and preservation indicators.

\begin{tabular}{|c|c|c|c|c|c|c|c|}
\hline Site & Element & Collagen yield (\%) & $\% \mathrm{C}$ (mass) & $\% \mathrm{~N}$ (mass) & $\mathrm{C} / \mathrm{N}$ (atomic) & $\mathrm{d}^{13} \mathrm{C}$ (\% $\left.\mathrm{PDB}\right)$ & $\mathrm{d}^{15} \mathrm{~N}$ (\% AIR) \\
\hline Lokomotiv & Vertebra & 14.3 & 43.9 & 16.2 & 3.2 & -20.2 & 9.7 \\
\hline Shamanka II & Vertebra & 14.2 & 44.5 & 16.6 & 3.1 & -16.1 & 13.0 \\
\hline
\end{tabular}

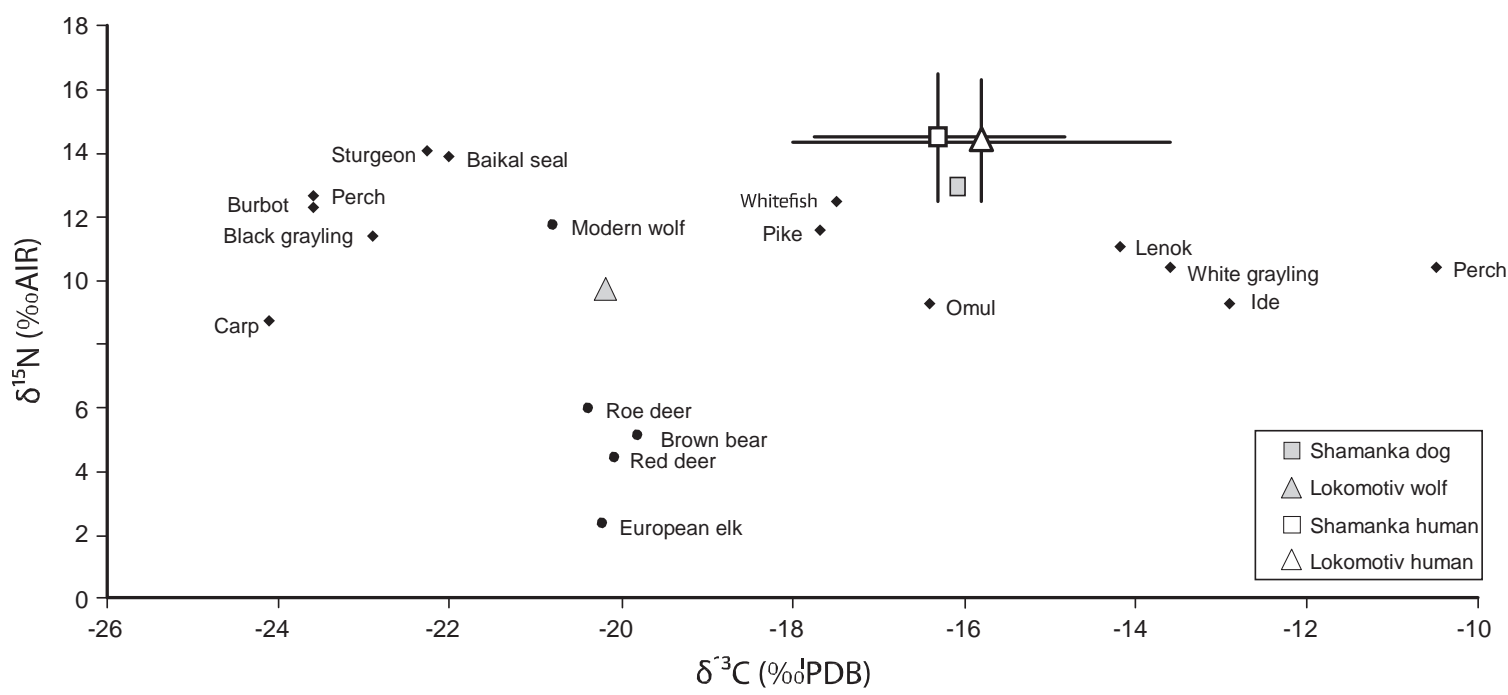

Fig. 10. Bone values for canids, humans, and modern and archaeological Cis-Baikal fauna.

and somewhat lower $\mathrm{d}^{15} \mathrm{~N}$ (see Fig. 10). They differ substantially from the values of local terrestrial fauna, and have been interpreted elsewhere (Katzenberg and Weber, 1999; Weber et al., 2002; Katzenberg et al., 2010) as indicating a mixed diet rich in aquatic resources. In contrast, the values of the Lokomotiv wolf $\left(d^{13} \mathrm{C}=-20.2 \%\right.$ o, $d^{15} \mathrm{~N}=9.7 \%$ ) fall quite far from those of the Shamanka dog, Shamanka humans and Lokomotiv humans. The similarity of the wolf's $\mathrm{d}^{13} \mathrm{C}$ value to those of archaeological terrestrial ungulates from the region (red deer, roe deer, European elk) and the position of its $\mathrm{d}^{15} \mathrm{~N}$ value roughly one trophic level above red deer and roe deer suggest a diet based on terrestrial resources, unlike the diets of human groups from its era (Katzenberg and Weber, 1999; Katzenberg et al. 2009; Katzenberg et al., 2010). This interpretation is reinforced by the similarity of the Lokomotiv wolf values to values found for a modern wild wolf from the Baikal region (see Fig. 10).

The two canids' stable isotope values indicate that they consumed dissimilar diets in the years prior to their deaths. The diet of the Shamanka dog was broadly similar to the diet of humans interred at Shamanka, although its $\mathrm{d}^{15} \mathrm{~N}$ value is somewhat lower. In this, it is similar to dogs from many other archaeological cultures (e.g. Katzenberg, 1989; Cannon et al., 1999; Boric et al., 2004; Fischer et al., 2007; Fornander et al., 2008). The values of the Lokomotiv wolf, on the other hand, are consistent with a diet of terrestrial ungulates, falling into the same area as a modern Baikal wolf. This is not suggestive of human provisioning, and indicates that whatever its relationship with the humans interred at Lokomotiv, it did not share their diet.

\section{Discussion and conclusions}

The treatments afforded canids in Cis-Baikal's Middle Holocene archaeological sites suggest that dogs and wolves were understood in a variety of ways. Some appear casually treated upon death while others received lavish care, often on par with that given to the human dead. Recurrently utilized human burial places (cemeteries) first appear in Cis-Baikal just over 8000 BP (Weber et al., 2010). At virtually the same time, the first canid burial appears, namely the wolf found at Lokomotiv, followed shortly thereafter by dog burials at Shamanka, Khuzhir, and perhaps Ust'-Belaia. At these first three sites whole canid bodies were buried in graves within which humans also were interred. However, there is no compelling evidence they were killed to be buried with a recently deceased human. The Shamanka canid was perhaps the first in a series of interments in a grave, and was subsequently disturbed by an episode of grave pit reentry. At Lokomotiv, human remains may have been removed from the grave prior to the wolf's burial. Subsequently the wolf was interred with a head of a human. Two of the Khuzhir canids were found with human remains, but separated from them by a layer of birch bark. Dogs were interred in their own pits at Ust'-Belaia and Khuzhir, complete with rare items such as roe deer antlers and materials typically only seen with humans such as red deer canine pendants and spoons. At Pad' Lenkovka a dog was buried in a relatively elaborate stone-lined grave. These patterns suggest that one wolf and many dogs in Cis-Baikal were considered persons and therefore treated much as humans were upon their deaths. They were transported to burial places, placed into graves, and sometimes provided with implements, ornaments, and other objects. Wolf and dog remains, as well as body parts of sable and fox (identified ethnographically as impure and contaminating) were found in Cis-Baikal graves near human bodies and were sometimes modified, perhaps for use as personal adornments. This further suggests that some canids and other carnivores were not considered contaminating but rather were kept close at hand, even in death.

The Shamanka specimen appears to have been a Husky, Chow Chow, or Samoyed-like male dog that stood roughly $60 \mathrm{~cm}$ tall at the shoulder. Recall that several other Middle Holocene dogs buried in Cis-Baikal also were identified as being Husky-like. The 
Shamanka dog's skeleton was fully fused and its teeth well worn, suggesting it was at least middle-aged. As an adult, the dog had suffered from one or more injuries to the spine and ribs, perhaps the result of blows from a human or other animal, or its use as a burden animal. These injuries had partially healed prior to death. Carbon and nitrogen stable isotope signatures indicate that its diet was similar to that of contemporaneous humans buried at Shamanka. Overall, these data suggest the Shamanka dog dwelt in close contact with humans, sharing their foods and perhaps assisting in tasks such as hunting and transport. It is probable that this level of intimacy lasted several years, as the dog was fully adult at the time of its death. These seem ideal circumstances in which a dog could become known as a quite human-like person. At the time of the dog's death, human bodies in this region of Siberia were placed in graves within formal cemeteries, sometimes in pits that already contained other bodies. This is precisely the treatment shown the dog at its death.

The Lokomotiv canid is an adult male wolf that stood at least $73 \mathrm{~cm}$ at the shoulder, which appears to place it among the larger wolves (Mech, 1970, p. 12). We do not believe, however, that the specimen can be identified to subspecies as was asserted in Bazaliiskiy and Savelyev (2003). The wolf is almost certainly an older adult. While wolves in captivity can reach 15-16 years of age, wild wolves appear to quite rarely survive to half this age (c.f., Stephenson and Sexton, 1974) - the age estimate for the Lokomotiv specimen is $9 \pm 1$ years. Bahn (2003) suggested that the degree of tooth loss seen in this animal might indicate it received care in its latter years from humans. However, several studies show that wolves commonly suffer fractures, including those of the skull, as well as tooth and even foot loss (Rausch, 1966; Stephenson and Sexton, 1974; Stephenson and Johnson, 1973). The incidences of such injuries appear to be correlated with animal age, and males are slightly more prone to such injuries than females (Nielson, 1977). Clearly the Lokomotiv wolf's missing and worn teeth are sign of a long and perhaps treacherous life, but not indicative of care by humans. Stable isotope analyses of bone from the wolf give no indication that the animal was eating a diet similar to the humans buried at Lokomotiv in the latter years of its life. Its diet appears to have focused on ungulates, the predominant prey of wolves today in this region of Siberia (Stroganov, 1969; Novikov, 1962). In short, the only evidence for this animal having an interaction with humans is its burial at the Lokomotiv cemetery.

What then might explain this unusual burial? Concepts such as friendship and companionship seem inappropriate as explanations, as the wolf does not appear to have been closely associated with humans except at death. It is possible the animal was encountered during the course of its life, perhaps when pursuing the same prey as human hunters. Perhaps humans witnessed its death or found the animal very shortly after it had perished. Regardless, at its death - the cause of which is not clear but could simply be old age - the animal was transported to Lokomotiv and given mortuary treatment equivalent to that given to a human person. It is the wolf's interment with a human head that is most provocative. It seems to have been positioned to surround or protect this specific individual, found nestled between its legs. In ethnographic cases described earlier, canids were clearly seen as protectors and transporters of human souls, but in these cases dogs (not wolves) were killed and their bodies, or portions of them, were placed in graves for this purpose. It seems possible the human head was from an earlier burial in this same grave that was exhumed, and then carefully placed back in the grave with the wolf. Perhaps then the wolf was not just treated as a person but was also meant as a protector of a specific human, likely one of the earliest buried at the cemetery.

Our study of the Lokomotiv and Shamanka specimens provides new details about the lives of two Cis-Baikal canids that received specialized post-mortem care. Along with a generalized model of how wolves, dogs, and other animals are variously understood in the North, these osteobiographies made possible a thorough interpretation of the meanings behind the burials. To further this research, additional studies of such detail are needed on other canids from this and other regions of Eastern Siberia, which to date are virtually non-existent. Such studies should include canid remains from all contexts, not just burials, as this will help in evaluating why only some canids' remains received distinct treatment. Social and emotional attachment to dogs probably did play a part in why some select few were buried, but emotion alone does not fully explain why they were given mortuary treatments similar to their human counterparts. It is clear that dogs and wolves are only two among many animals in the circumpolar North to receive distinct post-mortem treatment, including burial in graves (Grøn, 2005; Hallowell, 1926; Jordan, 2003; Paulson, 1968). This alone points to the fact that there is more to mortuary rites in any culture than mourning the death of a companion-ontological, cosmological, political, social, and other cultural and historical factors too shape these practices. We developed our interpretive model to address these complicated issues, and we hope that its integration with an osteobiographical approach can serve as a useful starting point for other researchers investigating human-animal relations within traditional societies.

\section{Acknowledgments}

Funding for this research was provided through grants from the Gerda Henkel Stiftung, the Wenner Gren Foundation for Anthropological Research, the Social Sciences and Humanities Research Council of Canada, and the Swedish Research Council. Special thanks go to the Royal Alberta Museum for providing access to wolf and dog materials in their collections. Andrzej Weber, Tatiana Nomokonova, Petr Kurzibov, and Lacey Fleming's assistance with various aspects of the project was greatly appreciated. Natalia Kaprishina is thanked for producing the illustrations.

\section{References}

Allitt, S., Stewart, R.M., Messner, T., 2008. The utility of dog bone (Canis familiaris) in stable isotope studies for investigating the presence of prehistoric maize (Zea mays ssp. mays): a preliminary study. North American Archaeologist 29, 343367.

Ambrose, S.H., 1990. Preparation and characterization of bone and tooth collagen for isotopic analysis. Journal of Archaeological Science 17, 431-451.

Ascough, P.L., Cook, G.T., Church, M.J., Dugmore, A.J., McGovern, T.H., Dunbar, E. Einarsson, A., Fridriksson, A., Gestsdottir, H., 2007. Reservoirs and radiocarbon: $14 \mathrm{C}$ dating problems in Myvatnssveit, Northern Iceland. Radiocarbon 49, 947961.

Bahn, Paul (Ed.), 2003. Written in Bones: How Human Remains Unlock the Secrets of the Dead. Firefly Books, Toronto.

Bazaliiskii, V.I., 2003. The neolithic of the Baikal Region on the basis of mortuary materials. In: McKenzie, H., Weber, A. (Eds.), Prehistoric Foragers of the Cisbaikal, Siberia. Canadian Circumpolar Press, Edmonton, pp. 37-50.

Bazaliiskii, V.I., Savel'ev, N.A., 2008. Mogil'nik epokhi rannego neolita Lokomotiv (osobennosti rituala zakhoronenii). In: Kharinskii, A.V. (Ed.), Izvestiia Laboratorii Drevnikh Tekhnologii, Izdatel'stvo Gosudarstvennogo Tekhnicheskogo Universiteta, Irkutsk, pp. 7-27 (in Russian).

Bazaliiskiy, V.I., Savelyev, N.A., 2003. The wolf of Baikal: the "Lokomotiv"' early Neolithic cemetery in Siberia (Russia). Antiquity 77, 20-30.

Barnett, R., Barnes, I., Phillips, M.J., Martin, L.D., Harington, C.R., Leonard, J.A., Cooper, A., 2005. Evolution of the extinct sabretooths (Smilodon and Homotherium) and American cheetahlike cat (Miracinonyx). Current Biology 15, 589-590.

Berdnikova, N.E., 2001. Geoarkheologicheskii ob'ekt Ust'-Belaia. Kul'turnye kompleksy. In: Kamennyi Vek Iuzhnogo Priangar'ia, Part II: Bel'skii Geoarkheologicheskii Raion, Irkutskii Gosudarstvennyi Universitet, Irkutsk, pp. 113-146 (in Russian).

Bird-David, N., 1990. The giving environment: another perspective on the economic system of hunter-gatherers. Current Anthropology 31, 189-196.

Bird-David, N., 1999. “Animism” revisited: personhood, environment, and relational epistemology. Current Anthropology 40, S67-S91. 
Boric, D., Grupe, G., Peters, J., Mikic, Z., 2004. Is the Mesolithic-Neolithic subsistence dichotomy real? New stable isotope evidence from the Danube Gorges. European Journal of Archaeology 7, 221-248.

Brewer, D., Clark, T., Phillips, A., 2001. Dogs in Antiquity: Anubis to Cerberus. Aris \& Phillips, Warminster, England.

Brightman, R., 1973. Grateful Prey. Rock Cree Human-Animal Relationships. University of California Press, Berkeley.

Cannon, A., Schwarcz, H.P., Knyf, H., 1999. Marine-based subsistence trends and the stable isotope analysis of dog bones from Namu, British Columbia. Journal of Archaeological Science 26, 399-407.

Colman, S.M., Jones, G.A., Rubin, M., King, J.W., Peck, J.A., Orem, W.H., 1996. AMS radiocarbon analyses from Lake Baikal, Siberia: challenges of dating sediments from a large, oligotrophic lake. Quaternary Science Reviews 15 (7), 669-684.

Conneller, C., 2004. Becoming deer. Corporal transformations at Starr Carr.. Archaeological Dialogues 11 (1), 37-56.

Cook, G.T., Bonsall, C., Hedges, R.E.M., McSweeney, K., Boronean, V., Pettitt, P.B., 2001. A freshwater diet-derived $14 \mathrm{C}$ reservoir effect at the stone age sites in the Iron Gates Gorge. Radiocarbon 43, 453-460.

Deevey Jr., E.S., Gross, M.S., Hutchinson, G.E., Kraybill, H.L., 1954. The natural 14C contents of materials from hard-water lakes. Proceedings of the National Academy of Sciences of the USA 40, 285-288.

Descola, P., 1992. Societies of nature and the nature of society. In: Kuper, A. (Ed.), Conceptualising Society. Routledge, London, pp. 107-126.

Emel'ianova, I.U.A., Kharinskii, A.V., Losey, R.J., 2009. Ispol'zovanie radiouglerodnogo metoda dlia datirovki poseleniia Baikal'skoe III (severnoe poberezh'e Baikala). In: Rol' Estestvenno-Nauchnykh Metodov v Arkheologicheskikh Issledovaniiakh, Altaiiskii Gosudarstvennyi Universitet, Barnaul, pp. 112-116 (in Russian).

Eriksson, G., Linderholm, A., Fornander, E., Kanstrup, M., Schoultz, P., Olofsson, H., Lidén, K., 2008. Same island, different diet: cultural evolution of food practice on Öland, Sweden, from the Mesolithic to the Roman Period. Journal of Anthropological Archaeology 27, 520-543.

Ermolova, N.M., 1978. Teriofauna Doliny Angary v Pozdnem Antropogene. Nauka, Novosibirsk (in Russian).

Fausto, C., 2007. Feasting on people: eating animals and humans in Amazonia. Current Anthropology 48 (4), 497-530.

Fischer, A., Heinemeier, J., 2003. Freshwater reservoir effect in 14C dates of food residue on pottery. Radiocarbon 45, 449-465.

Fischer, A., Olsen, J., Richards, M., Heinemeier, J., Sveinbjörnsdóttir, Á.E., Bennike, P., 2007. Coast-inland mobility and diet in the Danish Mesolithic and Neolithic: evidence from stable isotope values of humans and dogs. Journal of Archaeological Science 34, 2125-2150.

Fladerer, F.A., Salcher-Jedrasiak, T., Umgeher-Mayer, S., 2009. Before the decline of the Mammoths: a reassessment of the $20 \mathrm{ka}$ Epiaurignacian site at Langmannersdorf in Lower Austria. In: Proceedings of the 51st Annual Meeting in Ljubljana of the Hugo Obermaier Society for Quaternary Research and Archaeology of the Stone Age. University of Ljubljana, Slovenia, pp. 19-20.

Fornander, E., Eriksson, G., Lidén, K., 2008. Wild at heart: approaching pitted ware identity, economy and cosmology through stable isotopes in skeletal material from the Neolithic site Korsnäs in Eastern Central Sweden. Journal of Anthropological Archaeology 27, 281-297.

Germonpré, M., Sablin, M.V., Stevens, R.E., Hedges, R.E.M., Hofreiter, M., Stiller, M., Després, V.R., 2009. Fossil dogs and wolves from Palaeolithic sites in Belgium, the Ukraine and Russia: osteometry, ancient DNA and stable isotopes. Journal of Archaeological Science 36 (2), 473-490.

Geyh, M.A., Schotterer, U., Grosjean, M., 1998. Temporal changes in the 14C reservoir effect in lakes. Radiocarbon 40, 921-931.

Goriunova, O.I., Novikov, A.G., Ziablin, L.P., Smotrova, V.I., 2004. Drevnie Pogrebeniia Mogil'nika Uliarba na Baikale (Neolit-Paleometall). Izdatel'stvo IAiE SO RAN, Novosibirsk (in Russian).

Goriunova, O.I., Ovodov, N.D., Novikov, A.G., 2007. Analiz faunisticheskikh materiialov s mnogosloinogo poseleniia Tyshkine III (oz. Baikal). In: Severnaia Evraziia v Antropogene: Chelovek, Paleotekhnologii, Geoekologiia, Etnologiia i Antropologiia, vol. 1. Izd-vo "Ottisk", Irkutsk, pp. 168-174 (in Russian).

Grøn, O., 2005. A Siberian perspective on the north European Hamburgian culture: a study in applied hunter-gatherer ethnoarchaeology. Before Farming 1, 1-29.

Gutherie, S., 1993. Faces in the Clouds: A New Theory of Religion. Oxford University Press, Oxford.

Hallowell, I., 1926. Bear ceremonialism in the northern hemisphere. American Anthropologist, New Series 28, 1-175.

Harcourt, R.A., 1974. The dog in prehistoric and early historic Britain. Journal of Archaeological Science 1, 151-175.

Harvey, G., 2006. Animism: Respecting the Living World. Columbia University Press, New York.

Hulzcrantz, A., 1953. Conceptions of the Soul Among North American Indians. Ethnographical Museum of Sweden Monograph Series No. 1, Stockholm.

Ides, I., Brandt, A., 1967. Zapiski o Russkom Posol'stve v Kitae (1692-1695). Vostochnaia Literatura, Moscow (in Russian).

Ingold, T., 1986. The Appropriation of Nature. Manchester University Press, Manchester.

Ingold, T., 1996. Hunting and gathering as a way of perceiving an environment. In: Ellen, R., Kukui, K. (Eds.), Redefining Nature. Berg, London, pp. 117-155.

Ingold, T., 1998. Totemism, animism, and the depictions of animals. In: Seppala, M., Vanhala, J.-P., Weintraub, L. (Eds.), Animal, Anima, Animus, Pori Art Museum, Pori, pp. 181-207.

Ingold, T., 2000. The Perception of the Environment. Routledge, London.
Jensen, B., 1961. Folkways of Greenland dog-keeping. Folk 3, 43-66.

Jordan, P., 2003. Material Culture and Sacred Landscape: The Anthropology of the Siberian Khanty. AltaMira Press, Walnut Creek.

Katzenberg, M.A., 1989. Stable isotope analysis of archaeological faunal remains from Southern Ontario. Journal of Archaeological Science 16, 319-329.

Katzenberg, M.A., Weber, A.W., 1999. Stable isotope ecology and paleodiet in the Lake Baikal region of Siberia. Journal of Archaeological Science 26 (6), 651-659.

Katzenberg, M.A., Goriunova, O.I., Weber, A.W., 2009. Paleodiet reconstruction of Early Bronze Age Siberians from the site of Khuzhir-Nuge XIV, Lake Baikal. Journal of Archaeological Science 36, 663-674.

Katzenberg, M.A., Bazaliiskii, V.I., Goriunova, O.I., Savel’ev, N.A., Weber, A.W., 2010. Diet reconstruction of prehistoric hunter-gatherers in the Lake Baikal region. In: Weber, A.W., Katzenberg, M.A., Schurr, T.G. (Eds.), Prehistoric HunterGatherers of the Baikal Region, Siberia. University of Pennsylvania Museum of Archaeology and Anthropology, Philadelphia, pp. 175-191.

Klement'ev, A.M., Igumnova, E.A., Savel'ev, N.A., 2005. Khishchniki (Carnivora, Mammalia) Ust'-Khaitinskogo arkheologicheskogo mestohakhozhdeniia [Carnivores (Carnovore, Mammalia) of archaeological site Ust'-Khaita]. In: Istoki, Formirovanie i Razvitie Evraziiskoi Polikul'turnosti. Kul'tury i Obshchestva Severnoi Azii v Istoricheskom Proshlom i Sovremennosti: Mat-Ly I (XLV) Konf. Isdatel’stvo RPTS “Radian”, Irkutsk, pp. 26-29 (in Russian).

Konopatskii, A.K., 1982. Drevnie Kul'tury Baikala. Nauka, Novosibirsk (in Russian).

Krizhevskaia, L.I.A., 1978. Neolit poseleniia v ust'e r.Belaia (po materialam raskopok 1957 i 1959 gg.). In: Vasilevskii, P.S. (Ed.), Drevnie Kul’tury Priangar'ia. Nauka, Novosibirsk, pp. 69-95 (in Russian).

Larsson, L., 1989. Big dog and poor man: mortuary practices in Mesolithic Societies in Southern Sweden. In: Larsson, T.B., Lundmark, H. (Eds.), Approaches to Swedish Prehistory. BAR International Series 500, British Archaeological Reports, Oxford, pp. 211-223.

Le Bras-Goude, G., Claustre, F., 2009. Exploitation of domestic mammals in the Eastern Pyrenees during the Neolithic: human dietary patterns at the site of Montou (Corbères-les-Cabanes, France) using bone collagen stable isotopes $\left(d^{13} \mathrm{C}, \mathrm{d}^{15} \mathrm{~N}\right)$. Vie et Milieu - Life and Environment 59, 215-221.

Leonard, J.A., Wayne, R.K., Cooper, A., 2000. Population genetics of Ice Age brown bears. Proceedings of the National Academy of Sciences of the USA 97, 16511654.

Leonard, J.A., Wayne, R.K., Wheeler, J., Valadez, R., Guillén, S., Vilà, C., 2002. Ancient DNA evidence for Old World origin of New World dogs. Science 298, 16131616.

Leonard, J.A., Shanks, O., Hofreiter, M., Kreuz, E., Hodges, L., Ream, W., Wayne, R.K., Fleischer, R.C., 2007. Animal DNA in PCR reagents plagues ancient DNA research. Journal of Archaeological Science 34, 1361-1366.

Lieverse, A.R., Weber, A.W., Bazaliiskiy, V.I., Goriunova, O.I., Savel'ev, N.A., 2007 a. Osteoarthritis in Siberia's Cis-Baikal: skeletal indicators of hunter-gatherer adaptation and cultural change. American Journal of Physical Anthropology 132, $1-16$.

Lieverse, A.R., Link, D.W., Bazaliiskiy, V.I., Goriunova, O.I., Weber, A.W., 2007b. Dental health indicators in hunter-gatherer adaptation and culture change in Siberia's Cis-Baikal. American Journal of Physical Anthropology 134, 323-339.

Lieverse, A.R., Bazaliiskii, V.I., Goriunova, O.I., Weber, A.W., 2009. Upper limb musculoskeletal stress markers among Middle Holocene foragers of Siberia's Cis-Baikal region. American Journal of Physical Anthropology 138, 458-472.

Link, D.W., 1999. Boreal forest hunter-gatherer demography and health during the middle Holocene of the Cis-Baikal, Siberia. Arctic Anthropology 36, 51-72.

Mamonova, N.N., Sulerzhitskii, L.D., 1989. Opyt datirovaniia po C14 pogrebenii Pribaikal'ia epokhi golotsena. Sovetskaia Arkheologiia 1, 19-32.

McKenzie, H.G., Weber, A.W., Goriunova, O.I., 2008. Mortuary variability. In: Weber, A.W., Goriunova, O.I., McKenzie, H.G. (Eds.), Khuzhir-Nuge XIV, A Middle Holocene Hunter-Gatherer Cemetery on Lake Baikal, Siberia. Canadian Circumpolar Institute Press, Edmonton, pp. 219-266.

Mech, L.D., 1970. The Wolf: The Ecology and Behaviour of An Endangered Species. University of Minnesota Press, Minneapolis.

Medvedev, G.I., 1971. Mesolit Verkhnego Priangar'ia. Part I: Pamiatniki AngaroBel'skogo i Angaro-Idinskogo raionov. Irkutskii Gosudarstvennyi Universitet, Irkutsk (in Russian).

Mooder, K.P., Weber, A.W., Schurr, T.G., Bamforth, F.J., Bazaliiski, V.I., Savel'ev, N.A., 2005. Matrilineal affinities and prehistoric Siberian mortuary practices: a case study from Neolithic Lake Baikal. Journal of Archaeological Science 4, 619-634.

Mooder, K.P., Schurr, T.G., Bamforth, F.J., Bazaliiski, V.I., Savel'ev, N.A., 2006 Population affinities of Neolithic Siberians: a snapshot from Prehistoric Lake Baikal. American Journal of Physical Anthropology 129, 349-361.

Moreton, S.G., Rosqvist, G.C., Davies, S.J., Bentley, M.J., 2004. Radiocarbon reservoir ages from freshwater lakes, South Georgia, Sub-Antarctic: modern analogues from particulate organic matter and surface sediments. Radiocarbon 46, 621626.

Morey, D.F., 1992. Size, shape and development in the evolution of the domestic dog. Journal of Archaeological Science 19, 181-204.

Morey, D.F., 2006. Burying key evidence. The social bond between dogs and people. Journal of Archaeological Science 33 (2), 158-175.

Morey, D.F., 2010. Dogs: Domestication and the Development of a Social Bond. Cambridge University Press, Cambridge.

Morgan, J.P., 1967. Spondylosis Deformans in the Dog. Acta Orthopaedica Scandinavia Supplematum No. 96. Munksgaard, Copenhagen.

Muñoz-Fuentes, V., Darimont, C.T., Paquet, P., Leonard, J.A., 2010. The genetic legacy of extirpation and re-colonization in Vancouver Island wolves. Conservation Genetics 11, 547-556. 
Musiani, M., Leonard, J.A., Cluff, H.D., Gates, C.C., Mariani, S., Paquet, P.C., Vilà, C., Wayne, R.K., 2007. Differentiation of tundra/taiga boreal coniferous forest wolves: genetics, coat color and association with migratory caribou. Molecular Ecology 16, 4149-4170.

Nielsen, E.K., Petersen, E.B., 1993. Burials, People and Dogs. In: Hvass, S., Storgaard, B. (Eds.), Digging Into the Past: 25 Years of Archaeology in Denmark. Royal Society of Northern Antiquities, Copenhagen.

Nielson, C.A., 1977. Wolf Necropsy Report: Preliminary Pathological Observations. Special Report, Federal Aid in Wildlife Restoration Projects W-17-8 and W-1719. Alaska Department of Fish and Game, Juneau.

Nomokonova, T.IU., Losey, R.J., Goriunova, O.I., 2009. Fauna s mnogosloinogo poseleniia Berloga (Maloe More, ozero Baikal). In: Problemy Arkheologii, Etnografii, Antropologii Sibiri i Sopredel'nykh Terrotorii, vol. 15. Isd-vo IAiE SO RAN, Novosibirsk, pp. 177-181 (in Russian).

Nomokonova, T.IU, Goriunova, O.I., Losey, R.J., Savel'ev, N.A., in press. Ispol'zovanie bukhty Ulan-Khada na ozere Baikal $\mathrm{v}$ golotsene: po resul'tatam analiza faunisticheskikh materialov. Archaeology, Ethnology, and Anthropology of Eurasia (in Russian).

Novikov, G.A., 1962. Carnivorous Mammals of the Fauna of the USSR. Israel Program for Scientific Translation Ltd., Jerusalem.

Ohtsuka, K., 1994. Nivkh seal hunting and ritual. Bulletin of the National Museum of Ethnology 19 (4), 543-585 (in Japanese).

Okladnikov, A.P., 1955. Neolit i bronzovyi vek Prebaikal'ia (chast' III). In: Materia i issledovaniia po arkheologii SSSR, vol. 43. Izdatel'stvo Akademii nauk SSSR, Moscow (in Russian).

Okladnikov, A.P., 1974. Neoliticheskie Pamiatniki Angary (ot Shchukino do Bureti) Nauka, Novosibirsk (in Russian).

Olsen, S.J., 1985. Origins of the Domestic Dog: The Fossil Record. University of Arizona Press, Tucson.

Ovodov, N.D., Goriunova, O.I., Novikov, A.G., Weber, A.W., 2009. Faunisticheskie ostatki i kostianye izdeliia iz pogrebenii bronzovogo veka mogil’nika Kurma XI (ozero Baikal). In: Problemy Arkheologii, Etnografii, Antropologii Sibiri i Sopredel'nykh Terrotorii, Isd-vo IAiE SO RAN, Novosibirsk, vol. 15, pp. 366371 (in Russian).

Paulson, I., 1968. The preservation of animal bones in the hunting rites of some North-Eurasian peoples. In: Dioszegi, V. (Ed.), Popular Beliefs and Folklore Traditions in Siberia. Mouton and Co., The Hague, pp. 448-451.

Pederson, M.A., 2001. Totemism, animism, and North Asian indigenous ontologies. Journal of the Royal Anthropological Institute 7, 411-427.

Prokopenko, A.A., Williams, D.F., Karabanov, E.B., Khursevich, G.K., 1999. Response of Lake Baikal ecosystem to climate forcing and $\mathrm{pCO}_{2}$ change over the last glacial/interglacial transition. Earth and Planetary Science Letters 172 (3-4), 239-253.

Radovanovic, I., 1999. 'Neither person nor beast': dogs in the burial practice of the Iron Gates Mesolithic. Documenta Praehistorica 26, 71-87.

Rasmusen, K., 1930. Intellectual Culture of the Caribou Eskimos. Iglulik and Caribou Texts. Report of the Fifth Thule Expédition, 1921-1924, vol. 7, nos. 2-3 (Gyldendalske Boghandel, Nordisk Forlag, Copenhagen).

Rausch, R.A., 1966. Wolf Studies, 1964-1966. Federal Aid in Wildlife Restoration Work Plan Segment, Report W-6-R-5 and 6.

Salcher-Jedrasiak, T.A., Umgeher-Mayer, S., 2010. Die jungpaläolithische Freilandstation Langmannersdorf an der Perschling, Niederösterreich. Österreichische Akademie der Wissenschaften, Vienna, Austria (in German).

Samar, A.P., 2009. The Role of Dogs in Nanai Cults. In: Sasaki, S. (Ed.), HumanNature Relations and the Historical Backgrounds of Hunter-Gatherer Cultures in Northeast Asian Forests. Senri Ethnological Studies. National Museum of Ethnology, Osaka, vol. 72, pp. 145-160.

Schwartz, M., 1997. A History of Dogs in the Early Americas. Yale University Press, New Haven.

Sealy, J., 1986. Stable Carbon Isotopes and Prehistoric Diets in the South-western Cape Province, South Africa. Cambridge Monographs in African Archaeology 15, British Archaeology Report International Series, p. 293.

Sharma, D.K., Maldonado, J.E., Jhala, Y.V., Fleischer, R.C., 2003. Ancient wolf lineages in India. Proceedings of the Royal Society of London B 271 (Suppl.), S1-S4.

Shirokogoroff, S.M., 1935. Psychomental Complex of the Tungus. Kegan Paul, Trench, Trunbner and Co., London.

Snyder, L.M., Moore, E.A. (Eds.), 2006. Dogs and People in Social, Working, Economic or Symbolic Interaction. Oxbow Books, Oxford.

Spencer, R.F., 1959. The North Alaskan Eskimo: A Study in Ecology and Society. Smithsonian Institution Bureau of American Ethnology, Bulletin No. 117. US Government Printing Office, Washington, DC.

Stephenson, R.O., Johnson, L.J., 1973. Wolf Report, 1971-1972. Federal Aid in Wildlife Restoration Progress Report XI, W-17-4 and 5. Alaska Department of Fish and Game. Juneau, USA.
Stephenson, R.O., Sexton, J.J., 1974. Wolf Report, 1973. Federal Aid in Wildlife Restoration Progress Report XII, W-17-5 and 6. Alaska Department of Fish and Game, Juneau, USA.

Stringer, M.D., 1999. Rethinking animism: thoughts from the infancy of our discipline. Journal of the Royal Anthropological Institute 5, 541-555.

Stroganov, S.U., 1969. Carnivorous Mammals of Siberia. Israeli Program for Scientific Translations, Jerusalem.

Swofford, D.L., 2002. PAUP ${ }^{+}$; Phylogenetic Analysis Using Parsimony ( ${ }^{+}$and Other Methods). Sinauer, Sunderland, MA.

Taksami, C.M., 1968. Features of the Ancient Religious Rites and Taboos of the Nivkhi (Gilyaks). In: Dioszegi, V. (Ed.), Popular Beliefs and Folklore Traditions in Siberia. Mouton and Co., The Hague, pp. 407-421.

Teegan, W., 2002. Rib and vertebral fractures in midieval dogs from Haithabu, Starigard, and Schleswig. In: Davies, J., Fabis, M., Mainland, I., Richard, M., Thomas, R. (Eds.), Diet and Health in Past Animal Populations. Oxbow Books, Oxford, pp. 34-348.

Tilley, C., 1996. An Ethnography of the Neolithic: Early Prehistoric Societies in Southern Scandinavia. Cambridge University Press, Cambridge.

Turkin, G.V., Kharinskii, A.V., Fedorin, M.A., 2005. Khimicheskii sostav metallicheskikh predmetov mogil'nika Shamanka II na iuzhnom Baikale. Sotsiogenez v Severnoi Azii, vol. 1, pp. 169-175 (in Russian).

van Klinken, G.J., 1999. Bone collagen quality indicators for palaeodietary and radiocarbon measurements. Journal of Archaeological Science 26, 687-695.

Vdovin, I.S., 1977. Religioznye Kul'ty Chukchei. In: Pamiatniki Kul’tury Narodov Sibiri i Severa (Vtoraia Polovina XIX - Nachalo XX v.). Sbornik Muzeiia Antropogii i Etnografii XXXIII. Nauka, Moskva, pp. 117-171 (in Russian).

Vilà, C., Savolainen, P., Maldonado, J.E., Amorim, I.R., Rice, J.E., Honeycutt, R.L Crandall, K.A., Lundeberg, J., Wayne, R.K., 1997. Multiple and ancient origins of the domestic dog. Science 276, 1687-1689.

Vilà, C., Amorim, I.R., Leonard, J.A., Posada, D., Castroviejo, J., Petrucci-Fonseca, F., Crandall, K.A., Ellegren, H., Wayne, R.K., 1999. Mitochondrial DNA phylogeography and population history of the grey wolf Canis lupus. Molecular Ecology 8, 2089-2103.

Vitebsky, P., 2006. The Reindeer People: Living with Animals and Spirits in Siberia. Houghton Mifflin Company, Boston.

Viveiros de Castro, E., 1998. Cosmological deixis and Amerindian perspectivism. Journal of the Royal Anthropological Institute 4, 469-488.

Von den Driesch, A., 1976. A guide to the measurement of animal bones from archaeological sites. Peabody Museum of Archaeology and Ethnology 1, 1-137.

Warren, D.M., 2000. Paleopathology of Archaic dogs from the North American Southeast. In: Crockford, S.J. (Ed.), Dogs Through Time: An Archaeological Perspective. Archeaeopress, Oxford, pp. 105-114.

Watanabe, T., Nakamura, T., Watanabe Nara, F., Kakegawa, T., Horiuchi, K., Senda, R., Oda, T., Nishimura, M., Matsumoto, G.I., Kawai, T., 2009. High-time resolution AMS 14C data sets for Lake Baikal and Lake Hovsgol sediment cores: changes in radiocarbon age and sedimentation rates during the transition from the last glacial to the Holocene. Quaternary International 205, 2-20.

Weber, A.W., 1995. The neolithic and early bronze age of the lake Baikal Region, Siberia: a review of recent research. Journal of World Prehistory 9 (1), 99-165.

Weber, A., Link, D.W., Goriunova, O.I., Konopatskii, A.K., 1998. Patterns of prehistoric procurement of seal at Lake Baikal: a zooarchaeological contribution to the study of past foraging economies in Siberia. Journal of Archaeological Science 25, 215-227.

Weber, A.W., Link, D.W., Katzenberg, M.A., 2002. Hunter-gatherer culture change and continuity in the Middle Holocene Cis-Baikal, Siberia. Journal of Anthropological Archaeology 21, 230-299.

Weber, A.V., McKenzie, H.G., Beukens, R., Goriunova, O.I., 2005. Evaluation of radiocarbon dates from the Middle Holocene hunter-gatherer cemetery Khuzhir-Nuge XIV, Lake Baikal, Siberia. Journal of Archaeological Science 32, 1481-1500.

Weber, A.W., Beukens, R.P., Bazaliiskii, V.I., Goriunova, O.I., Savel'ev, N.A., 2006. Radiocarbon dates from Neolithic and Bronze Age hunter-gatherer cemeteries in the Cis-Baikal region of Siberia. Radiocarbon 48 (1), 127-166.

Weber, A.W., Katzenberg, M.A., Schurr, T.G. (Eds.), 2010. Prehistoric HunterGatherers of the Baikal Region, Siberia: Bioarchaeological Studies of Past Life Ways. University of Pennsylvania Museum of Archaeology and Anthropology, Philadelphia.

White, C.D., Pohl, M.E.D., Schwarcz, H.P., Longstaffe, F.J., 2001. Isotopic evidence for Maya patterns of deer and dog use at Preclassic Colha. Journal of Archaeological Science 28, 89-107.

Willerslev, R., 2007. Soul Hunters: Hunting, Animism, and Personhood Among the Siberian Yukaghirs. University of California Press, Berkeley. 